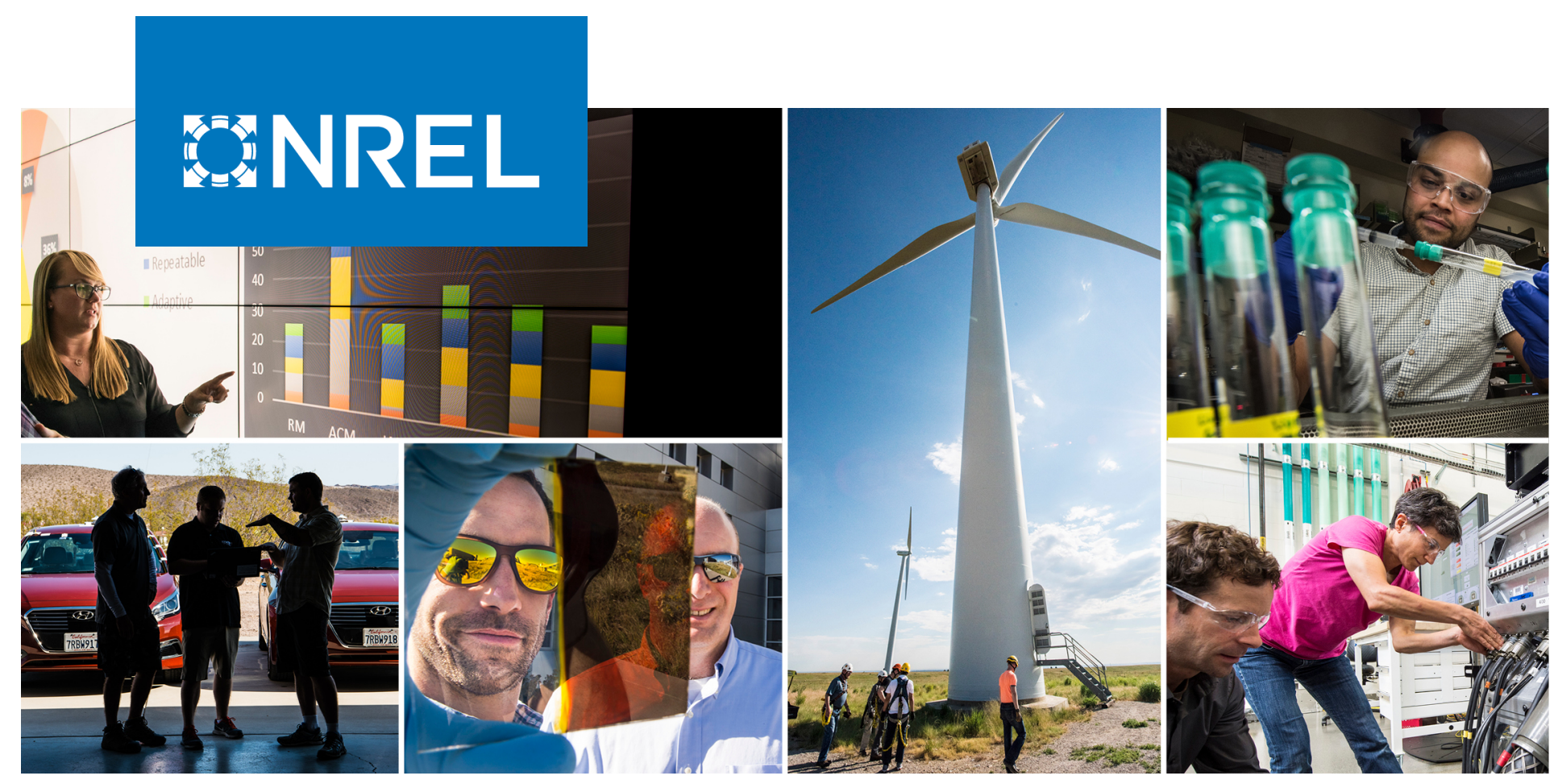

\title{
Voluntary Renewable Energy Procurement Programs in Regulated Utility Markets
}

Rob Hardison, Jenny Heeter, Sam Koebrich, and Bethany Speer

National Renewable Energy Laboratory

NREL is a national laboratory of the U.S. Department of Energy Office of Energy Efficiency \& Renewable Energy

Operated by the Alliance for Sustainable Energy, LLC

This report is available at no cost from the National Renewable Energy Laboratory (NREL) at www.nrel.gov/publications.
Technical Report

NREL/TP-6A20-76927

October 2020 


\title{
GNREL
}

\section{Voluntary Renewable Energy Procurement Programs in Regulated Utility Markets}

\author{
Rob Hardison, Jenny Heeter, Sam Koebrich, and \\ Bethany Speer
}

\section{National Renewable Energy Laboratory}

\section{Suggested Citation}

Hardison, Rob, Jenny Heeter, Sam Koebrich, and Bethany Speer. 2020. Voluntary

Renewable Energy Procurement Programs in Regulated Utility Markets. Golden, CO: National Renewable Energy Laboratory. NREL/TP-6A20-76927.

https://www.nrel.gov/docs/fy210sti/76927.pdf.

NREL is a national laboratory of the U.S. Department of Energy Office of Energy Efficiency \& Renewable Energy Operated by the Alliance for Sustainable Energy, LLC

This report is available at no cost from the National Renewable Energy Laboratory (NREL) at www.nrel.gov/publications.

Contract No. DE-AC36-08GO28308
Technical Report NREL/TP-6A20-76927

October 2020

National Renewable Energy Laboratory 15013 Denver West Parkway Golden, CO 80401 303-275-3000 • www.nrel.gov 


\section{NOTICE}

This work was authored by the National Renewable Energy Laboratory, operated by Alliance for Sustainable Energy, LLC, for the U.S. Department of Energy (DOE) under Contract No. DE-AC36-08GO28308. Funding was provided by the Children's Investment Fund Foundation. The views expressed herein do not necessarily represent the views of the DOE or the U.S. Government.

This report is available at no cost from the National Renewable Energy Laboratory (NREL) at www.nrel.gov/publications.

U.S. Department of Energy (DOE) reports produced after 1991 and a growing number of pre-1991 documents are available free via www.OSTI.gov.

Cover Photos by Dennis Schroeder: (clockwise, left to right) NREL 51934, NREL 45897, NREL 42160, NREL 45891, NREL 48097, NREL 46526.

NREL prints on paper that contains recycled content. 


\section{Acknowledgments}

The authors would like to thank the following individuals and their respective organizations for providing valuable technical insights toward the development of this work: Orrin Cook and Rachael Terada (Center for Resource Solutions), Jared Braslawski (International-REC Standard), Lars Kvale, Roble Velasco-Rosenheim, Julita Indah and Inu Suprianto (Perusahaan Listrik Negara), Ed Holt, Shailesh Telang (Carbon Disclosure Project), Jules Chuang and Andrea Yu (Mt. Stonegate), and Kelley Kizzier (Environmental Defense Fund). The authors would also like to thank the entire Clean Energy Investment Accelerator team in Indonesia for their insights, administrative support, and editorial improvements. In addition, the authors thank the following NREL staff for their helpful contributions and thoughtful reviews of this work: Jonathan Morgenstein, Kaifeng Xu, Jesse Cruce, Emily Fekete, Liz Breazeale, Isabel McCan, Barbara O’Neill, Dan Bilello, and Kristen Ardani. This report was made possible by the Children's Investment Fund Foundation. 


\section{List of Acronyms}

CEIA

CDP

$\mathrm{CN}$

FIT

GEOP

GHG

GO

GPP

IPP

I-REC

PPA

QRE

RE

REBA

REC

RPS

SBT

SBTi

SEDA

TIGR

WRI
Clean Energy Investment Accelerator

The Carbon Disclosure Project

carbon neutral

feed-in tariffs

Green Energy Option Program

greenhouse gas

Guarantee of Origin

green procurement program

independent power producer

International REC Standard

power purchase agreement

Qualified Reporting Entity

renewable energy

Renewable Energy Buyers Alliance

renewable energy certificate

renewable portfolio standard

science-based target

Science-Based Target initiative

Sustainable Energy Development Authority

Tradable Instrument for Global Renewables

World Resources Institute 


\section{Definitions}

Bundled renewable energy certificates (RECs): RECs sold together with the associated underlying electricity.

Compliance market: Markets where requirements for renewable energy (RE) generation are placed on electricity suppliers with financial penalties for suppliers that do not meet the specified obligations; also referred to as mandatory or compulsory markets.

Green procurement programs (GPPs): This term encompasses utility green pricing and utility green tariff programs that are tracked using RECs to verify sourcing.

Green pricing: Utility customers procure REC-backed electricity on a month-to-month basis through an added fee on their utility bill. RECs may or may not be sourced from RE resources located in the utility's service territory.

Green tariff: Utility customers procure REC-backed electricity from their utility through a special tariff or bilateral contract, typically on a long-term basis sourced from a new RE generator.

Independent power producer (IPP): A nonpublic entity that owns and operates facilities to generate electricity for sale to utilities or end users.

Liberalized market: Power markets that allow for resource and customer competition through private sector involvement and ownership of electricity generation, transmission and distribution assets, and operating roles.

Power purchase agreement (PPA): A contract for sale of electricity between two parties. It can be between an IPP and a utility, between an IPP and private customer, or between a utility and a private customer.

REC: RECs represent the RE attributes of one MWh of generation from a particular RE source. Because of the nature of the electricity grid-where electricity from a mix of generators flows to where it is needed rather than following a contractual pathway-RECs were created as an accounting method to track ownership claims on RE, which allows for monetization of the value of RE.

REC-based procurement program: Any RE procurement mechanism that utilizes RE registered under a REC tracking system. Includes direct REC sales, utility green pricing, utility green tariffs, and PPAs.

REC tracking system: An electronic accounting platform that provides the means for users to generate, verify, track transfers, and retire RECs; also referred to as a REC registry.

Renewable portfolio standard (RPS): A policy mechanism mandating an increasing amount of $\mathrm{RE}$ as a portion of the electricity supply. Also referred to as a renewable electricity standard and renewable. 
Traditionally regulated market: A market served by a public-sector or monopoly-granted utility, ranging from fully integrated utilities to those with a limited amount of private sector involvement in direct sale to end customers. Limited private sector roles may include some independent power production and transmission and distribution services.

Voluntary market: Where customers choose to procure RE to match a portion of their electricity consumption without any legal requirement to do so. 


\section{Table of Contents}

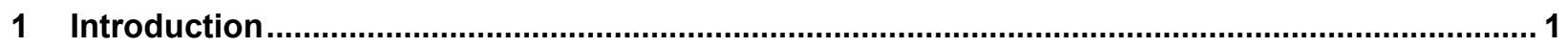

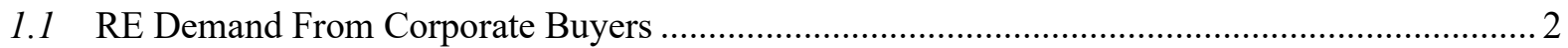

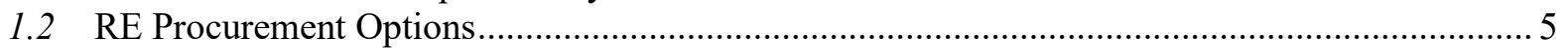

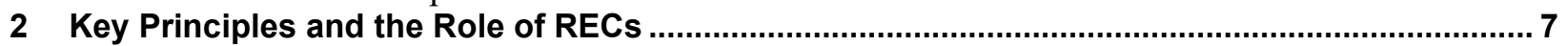

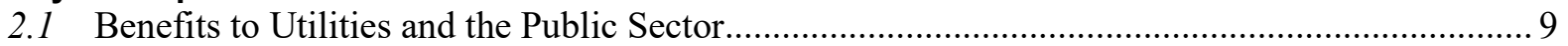

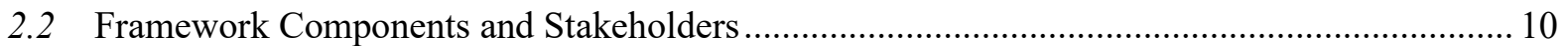

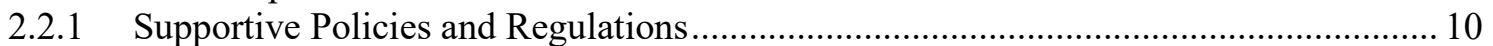

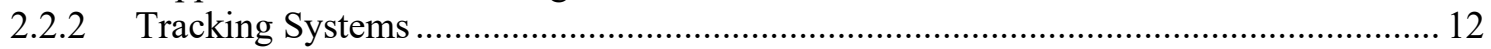

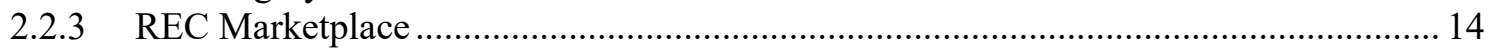

2.3 Additional Considerations: Interactions with Feed-In Tariffs, Carbon Accounting and Markets,

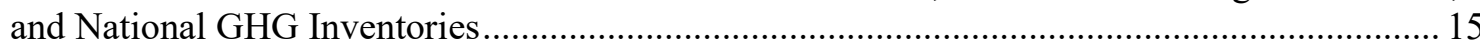

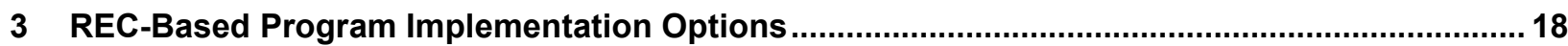

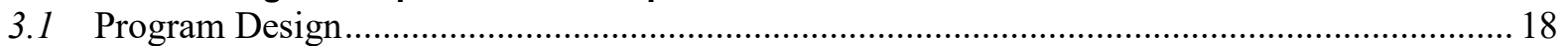

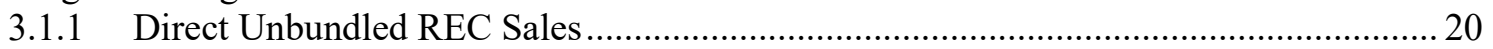

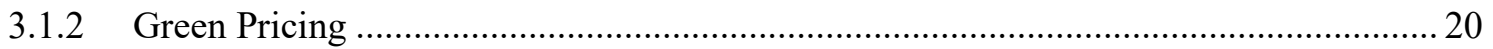

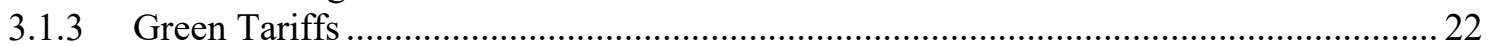

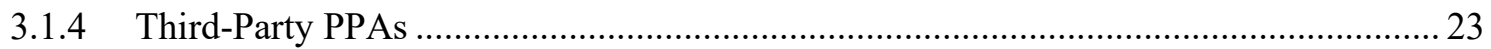

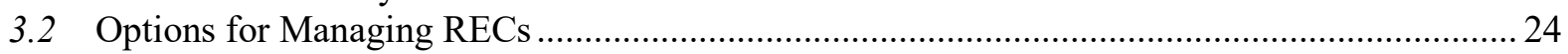

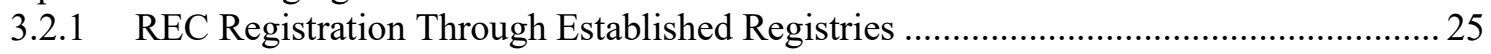

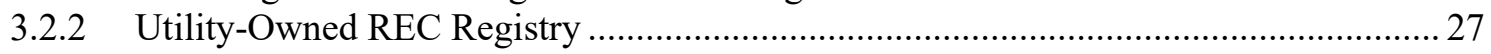

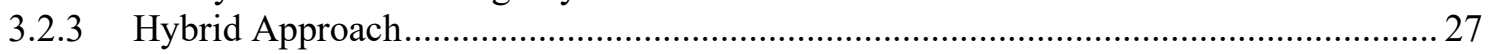

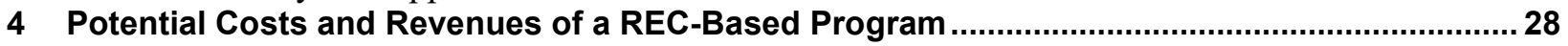

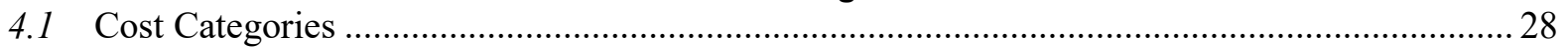

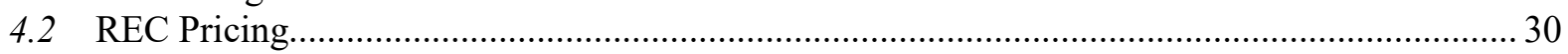

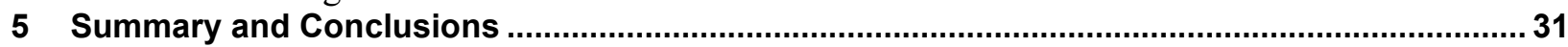

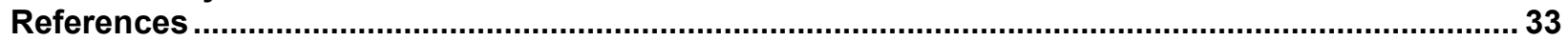

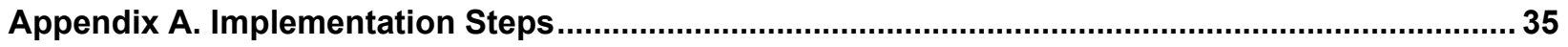




\section{List of Figures}

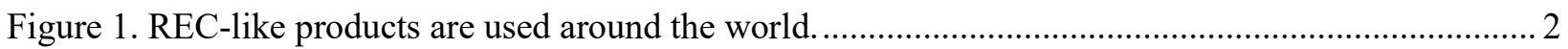

Figure 2. Percentage of Fortune 500 companies with public clean energy commitments .......................... 2

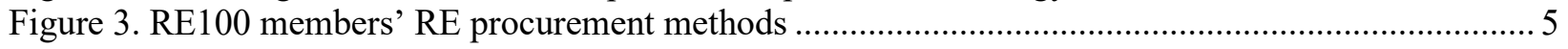

Figure 4. Global corporate PPAs by resources and size ............................................................... 6

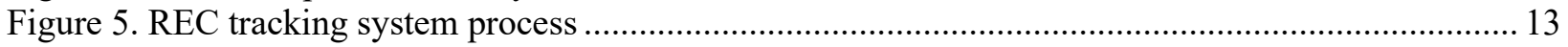

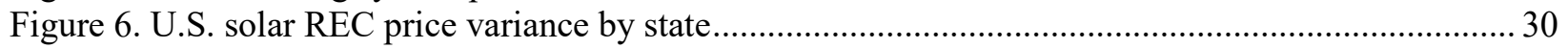

\section{List of Tables}

Table 1. Corporate RE Goal-Setting Programs................................................................................. 4

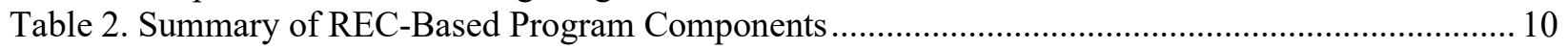

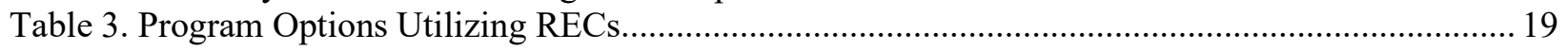

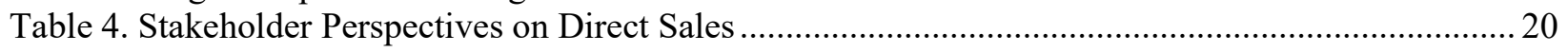

Table 5. Stakeholder Perspectives on Green Pricing ....................................................................... 21

Table 6. Stakeholder Perspectives on Green Tariffs ........................................................................... 23

Table 7. Stakeholder Perspectives on Third-Party PPAs/Leases .......................................................... 24

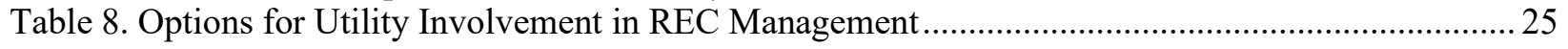

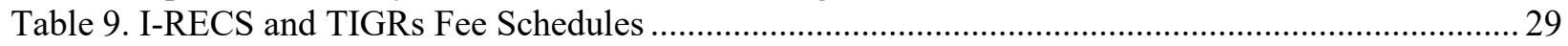

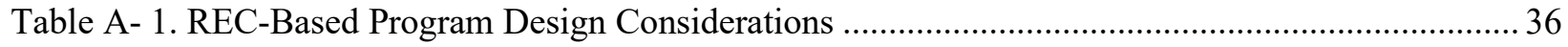

Table A- 2. REC Program Implementation Milestones ............................................................................ 38 


\section{Introduction}

Multinational corporations are increasingly purchasing renewable energy (RE) to fulfill international commitments, reduce supply chain emissions, limit environmental impact, and secure stable and affordable electricity (Motyka et al. 2019). The potential scale of global corporate RE purchasing has been estimated to be nearly $100 \mathrm{GW}$ and growing (Harrison 2020); however, many markets still lack supportive enabling environments for corporations to access $\mathrm{RE}$ through on-site project development or private sector transactions. Even where allowed by law, on-site generation may be insufficient due to space and technical constraints, introducing additional challenges. Utility green pricing and utility green tariff programs backed by renewable energy certificates (RECs), referred to as utility green procurement programs (GPPs) in this report, offer powerful market-based solutions to utilities, regulators, and policymakers to provide corporate and other consumers with RE product options while generating revenue to support RE development.

As RE markets expand around the globe, GPPs have proven to be effective mechanisms in market regimes, ranging from fully integrated state-owned utilities to broadly liberalized power markets. GPPs utilize RECs, which are a type of energy attribute certificate and closely resemble guarantees of origin, to track and ultimately monetize RE attributes that corporations and other buyers must procure to demonstrate progress against their RE commitments and make public claims of RE use. Time-tested and transparent REC accounting mechanisms provide market confidence, while at the same time offering flexibility to utilities, regulators, and customers for a range of applications.

RECs are used in all types of electricity market structures, as indicated in Figure 1, but RECbased program designs and supporting components differ depending on the type of market. Liberalized markets allow for customers to contract directly with generators for electricity and RECs, while traditionally regulated markets with vertically integrated utility structures may have greater restrictions on generation asset ownership and electricity sales. RE markets can be further defined as being either mandatory or voluntary. Mandatory markets require suppliers to deliver specified amounts of RE to grid customers, such as under a renewable portfolio standard (RPS), while voluntary markets involve no legal mandates, but demand is driven by self-imposed customer goals. 


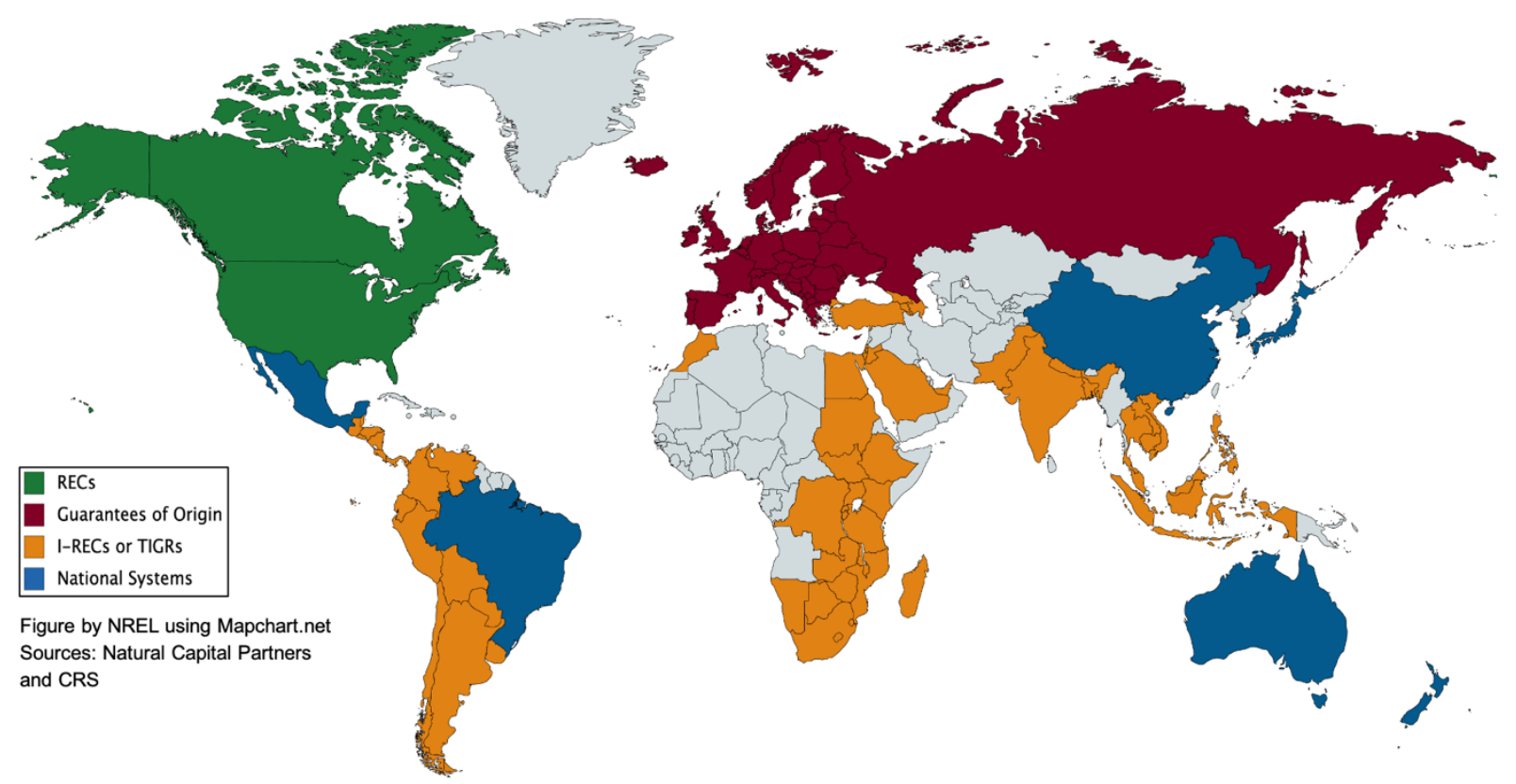

Figure 1. REC-like products are used around the world.

This report presents utilities, governments, policymakers, and corporate buyers with a primer on RECs and REC-based GPPs. This report focuses primarily on RECs and GPPs as they apply to variations of traditionally regulated, voluntary RE markets, but it can offer insights into the basic operating principles of all REC-based programs. This report largely focuses on the utility's perspective given its typical role as a primary actor in RE transactions in regulated power markets.

\subsection{RE Demand from Corporate Buyers}

Corporations are increasingly committing to source their energy from renewables. Figure 2 highlights the increase in Fortune 500 companies that have committed to some combination of being carbon neutral, using $100 \%$ RE (RE100), or setting a target under the Science-Based Target Initiative (SBTi). Such corporate demand offers a growing opportunity for RE generation capacity investment and expansion.
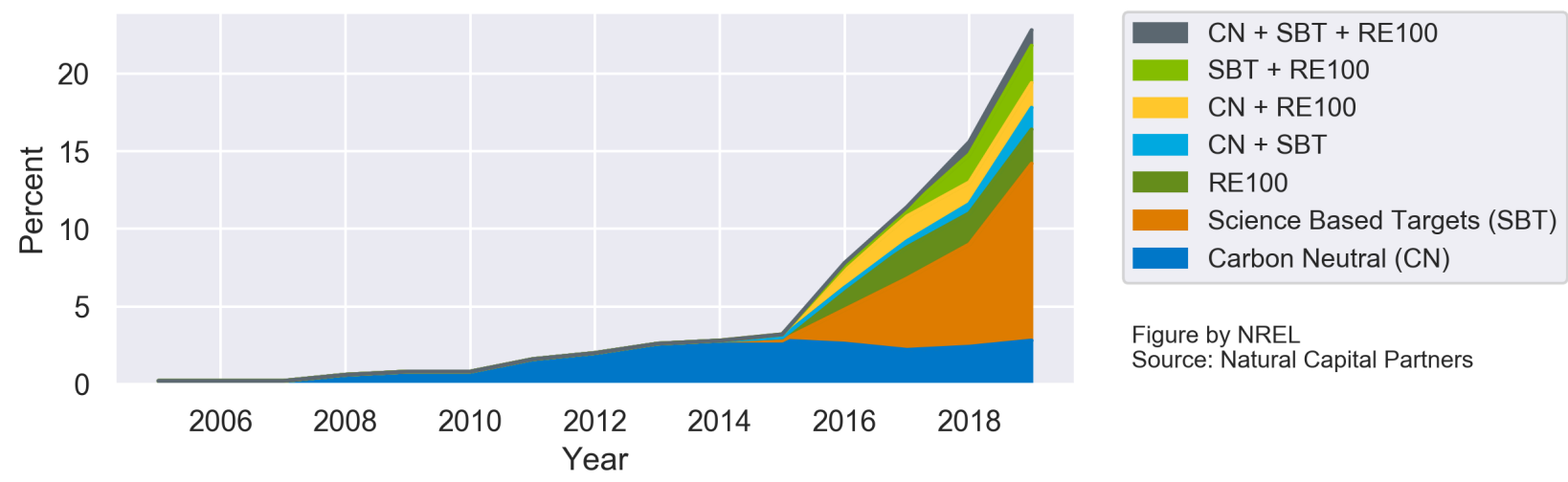

Figure by NREL

Source: Natural Capital Partners

Figure 2. Percentage of Fortune 500 companies with public clean energy commitments 
Voluntary RE commitment programs are helping to drive the growth in corporate RE goalsetting by working with stakeholders to establish guidelines aimed at maximizing the clean energy benefits of RE generation expansion. RE100, SBTi, and the Renewable Energy Buyers Alliance are three prominent organizations whose principles require the use of RECs for RE procurement claims. These programs are highlighted in Table 1. 
Table 1. Corporate RE Goal-Setting Programs

\begin{tabular}{|c|c|c|c|}
\hline Program & $\begin{array}{l}\text { Corporate } \\
\text { Membership }\end{array}$ & $\begin{array}{l}\text { Energy } \\
\text { Consumption } \\
\text { Represented } \\
\star \star \star *\end{array}$ & Description \\
\hline $\begin{array}{l}\text { Renewable } \\
\text { Energy } \\
\text { Buyers } \\
\text { Alliance } \\
\text { (REBA)* }^{*}\end{array}$ & 78 & 69 TWh & $\begin{array}{l}\text { A coalition of energy stakeholders aiming to } \\
\text { simplify RE procurement toward a zero-carbon } \\
\text { energy future. } \\
\text { Principles include: (1) Greater choice in } \\
\text { procurement options; (2) More access to cost- } \\
\text { competitive options; (3) Longer- and variable- } \\
\text { term contracts; (4) Access to new projects that } \\
\text { reduce emissions beyond business as usual; (5) } \\
\text { Increased access to third-party financing } \\
\text { vehicles, as well as standard and simplified } \\
\text { processes, contracts, and financing for RE } \\
\text { projects; and (6) Opportunities to work with } \\
\text { utilities and regulators to expand buying choices. }\end{array}$ \\
\hline $\begin{array}{l}\text { RE } 100 \\
\text { (Alarcon } \\
\text { and } \\
\text { Reynolds } \\
\text { 2019) }\end{array}$ & $\begin{array}{l}211 \text { across } \\
144 \\
\text { countries }\end{array}$ & $\begin{array}{l}80 \mathrm{TWh} \text { of } \\
\mathrm{RE}^{* * *}\end{array}$ & $\begin{array}{l}\text { Overseen by The Climate Group and The Carbon } \\
\text { Disclosure Project (CDP), RE100 is an } \\
\text { association of corporations pledging to work } \\
\text { toward } 100 \% \text { renewable electricity by } 2050 \text {. } \\
\text { Principles include: ambition, impactful } \\
\text { procurement, sustainability, influence, and } \\
\text { transparency. Unbundled RECs must be certified } \\
\text { by a third-party organization such as the Green-e } \\
\text { Energy certification program. }\end{array}$ \\
\hline SBTi** & 365 & $\begin{array}{l}90 \text { TWh of } \\
\mathrm{RE}^{* * *}\end{array}$ & $\begin{array}{l}\text { A collaboration between the World Resources } \\
\text { Institute (WRI), the UN Global Compact, CDP, } \\
\text { and the World Wildlife Fund working to gain } \\
\text { commitment from corporations to drive down } \\
\text { greenhouse gas (GHG) emissions. } \\
\text { Principles include: aligning RE industry RE } \\
\text { procurement targets with GHG emissions to keep } \\
\text { global temperature increases below } 2^{\circ} \text { Celsius. } \\
\text { Relies on WRI's Corporate Standard for RE } \\
\text { accounting, which requires use of RECs. }\end{array}$ \\
\hline
\end{tabular}


*Source: Buyersprinciples.org

${ }^{* *}$ Source: Sciencebasedtargets.org

${ }^{* * *}$ Amount of RE procurement if all targets are met.

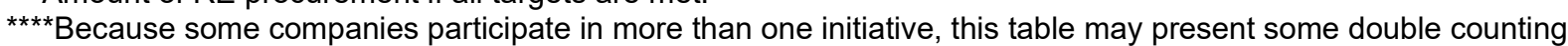
of energy consumption.

\subsection{RE Procurement Options}

International corporate RE procurement to date has been primarily through a mix of selfgeneration, power purchase agreements (PPAs) from off-site RE generators, GPPs from utility suppliers, and unbundled REC purchases. Figure 3 highlights the large annual increase in the use of these mechanisms for RE100 members, which surpassed $80 \mathrm{TWh}$ worldwide in 2018. This represented roughly $35 \%$ of these companies' nearly $230 \mathrm{TWh}$ of total electricity demand. While all procurement options have seen growth, off-site PPAs and unbundled REC purchases have grown the fastest in recent years (Alarcon and Reynolds 2019).

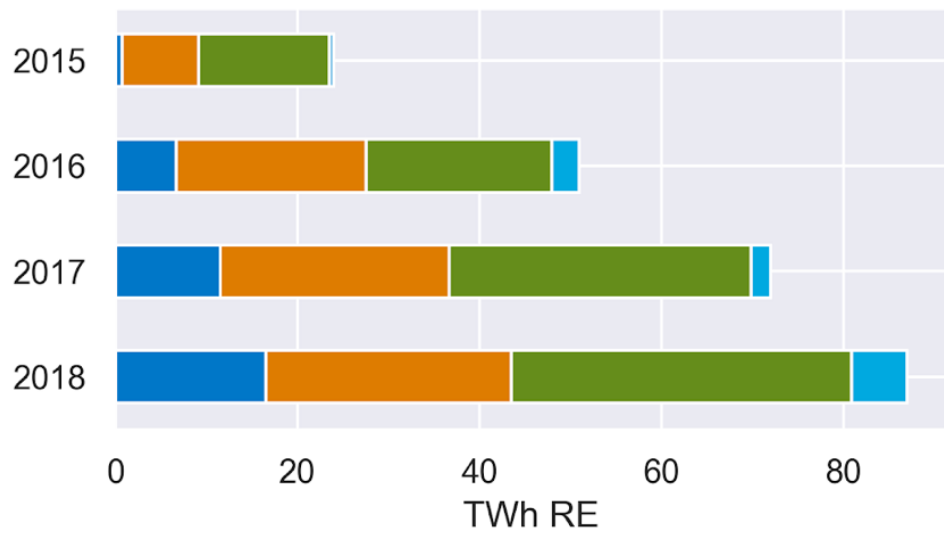

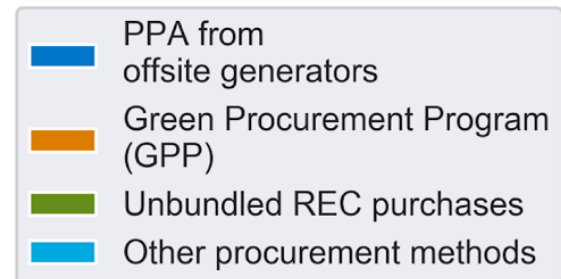

Figure by NREL

Source: 2019 RE100 Annual Report

Figure 3. RE100 members' RE procurement methods

Although off-site PPAs are increasing, there are regions where this option is not available. Figure 4 shows the scale and technology categorization of corporate PPAs signed to date across three markets: Asia, Europe, and the Americas. Most of the PPAs have been signed in Northern Europe (wind), Southern Europe (solar), California (Solar), and Central United States (wind). The Asian market has seen little adoption of PPAs, thereby representing an opportunity for new corporate renewable procurement as companies look to meet their RE goals on a global scale. 

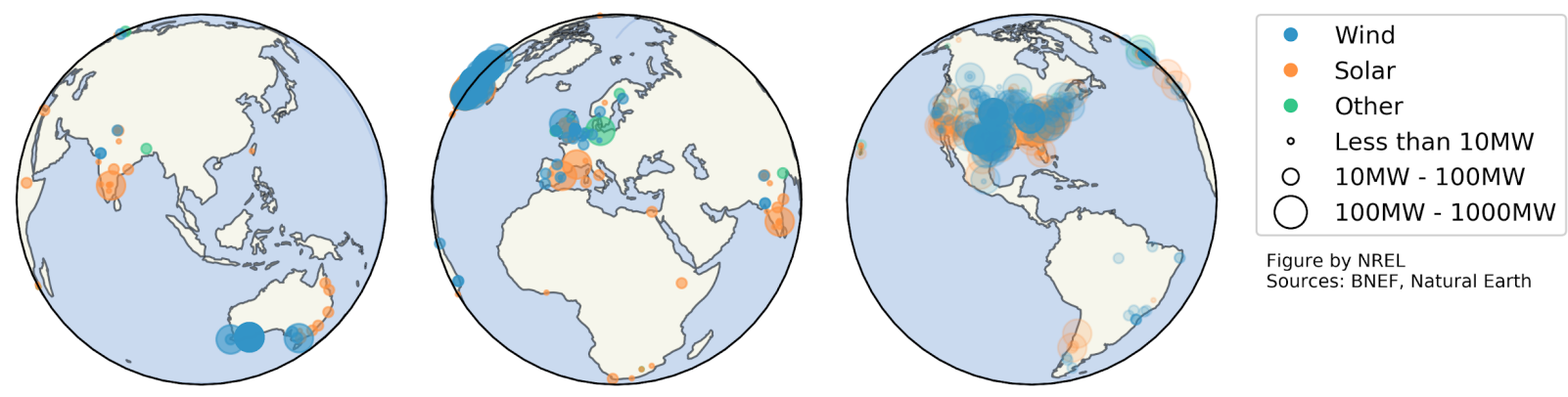

Figure 4. Global corporate PPAs by resources and size

Where policies or other circumstances do not support on-site project development or off-site PPAs, corporations can utilize GPPs or unbundled RECs to procure RE. In traditionally regulated markets, on-site projects and off-site PPAs are often hindered or prohibited by policy limitations such as rules stipulating that only utilities can sell electricity, unfavorable net metering regimes, or installation size and licensing limitations. Furthermore, technical capacity limitations may make it difficult for companies to identify capable RE project developers to install projects at prices and quality levels that compete with utility tariffs. Finally, companies may be unable to install RE on-site due to limited access to capital, prohibitive facility lease agreements, or unsuitable site conditions.

Utilities can capitalize on the flexibility of RECs to encourage private-sector investment in renewables while providing corporations with various ways to access off-site RE options. RECs can be sold directly to customers unbundled from electricity or incorporated into GPPs. Where allowed, RECs can also be generated from non-utility-owned projects and transferred to buyers through an array of transaction mechanisms; one innovative approach involves corporations investing directly in projects to serve as "REC factories" (CEIA corporate members, pers. comm.). Section 3 provides further details on the implementation options. 


\section{Key Principles and the Role of RECs}

RECs play a central role in RE procurement options by providing the mechanism for accounting and leveraging the value of RE to drive project development. They rely on REC tracking systems, or registries, to provide a means to manage REC generation, verification, and retirement. REC tracking systems provide the means for users to generate, verify, track transfers, and retire RECs. REC tracking systems are covered in more detail in Section 2.2.2.

The accounting role of RECs provides regulators and customers with a means to verify RE claims. For regulators, this is particularly applicable to compliance markets, such as those under an RPS, where the participants must be able to demonstrate valid RE purchases to avoid monetary or other legal penalties. In voluntary markets, corporate customers and the various goal-setting programs to which they belong demand that the RE claims being made toward meeting commitments are reliable so that their goals have the intended impact and are recognized globally.

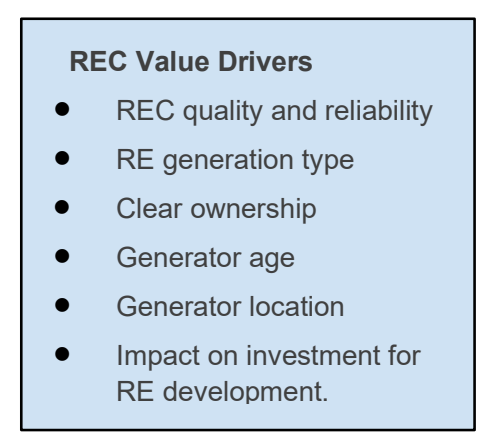

For corporate RE buyers, the value of RECs is based on three key aspects: (1) credibility; (2) affordability; and (3) impact (CEIA 2019). These preferences are often informed by the best practices developed and disseminated by goal-setting programs but may differ from company to company.

Essential to any RE product is ensuring that it is credible. The market confidence that RECbased programs provide is derived from standardized, transparent, and reliable procedures and systems for tracing and verifying RE generation amounts, sources, uniqueness, and clear ownership. REC tracking systems support this by managing and allowing visibility into REC transfers from generators to buyers, after-market trades, and ultimately, the REC retirements required for corporations to make credible RE procurement claims. REC tracking systems utilize third-party verification procedures to give buyers confidence that the RE they are sourcing is truly renewable and that the amount of RE generated is accurately presented. Reputable REC brokers require third-party certification as there is negligible demand for uncertified RECs (CEIA corporate survey, unpublished data; R. Velasco-Rosenheim, pers. comm.).

Third-party verification and certification ensure prevention of the following potential issues with RECs:

- Double-selling: The deliberate, or nondeliberate, action of selling the same REC to two entities.

- Double-counting: Two entities claim the same REC toward RE commitments or obligations.

- Double-claiming: One entity owns the REC, while another entity makes public or other claims on usage of the same RE. Under this principle, a utility (or other generator) that sells all the RECs from its owned RE generation to a corporate customer cannot make formal or informal statements in its marketing materials telling other customers that it is using 
renewable electricity. This is particularly applicable to corporate buyers under voluntary programs. $^{1}$

The confidence afforded by the accounting behind RECs translates to value that can be monetized and put to use to incentivize expansion of RE capacity. Appropriately designed REC markets, where the value flows to the investor, improve the economics of RE investments and help to make them more competitive with conventional electricity generation and incentivize growth in RE generation capacity. This is especially true in markets where there are mechanisms for long-term REC contracts that provide known REC prices over 15-20 years that can be built into a project's financial projections, such as through green tariff programs. RECs unbundled from electricity that are procured through spot markets provide revenue for sellers, but the revenue is typically too volatile to improve project bankability.

Companies are looking for products that are price-competitive with standard utility tariffs or direct RE installation costs and that provide the benefits they ascribe to RE. Although $\mathrm{RE}$ prices around the world are coming down, companies are often willing to pay a premium for the convenience, flexibility, and range of options REC-based programs can offer. Long-term contracts can provide certainty for cost planning and a hedge against price increases. Long-term bundled REC contracts can also be structured to provide savings compared to anticipated future utility prices. REC prices that buyers are willing to pay are ultimately driven by market forces such as supply and demand, the characteristics of the RE generation source, certification, and impact the RECs have on RE deployment. Sellers may set low prices to encourage uptake while still covering program management costs, but if the REC product does not meet buyers' requirements, demand and uptake may be hindered.

\section{Many companies, particularly those involved with international goal-setting, focus on} "impactful" purchasing. Companies may define impact in different ways, but it is generally related to supporting RE growth, local market conditions, and environmental conservation. For $\mathrm{RE}$ growth, which serves as a means of reducing climate impact, corporate customers typically seek RE from newer assets to drive demand for additional projects and increase overall RE deployment. Further, corporate customers demand that REC-based programs are designed so that revenues from RECs serve to incentivize new RE development, rather than simply providing additional revenue for utilities or governments with no plan to increase RE generation capacity.

The location of the generation source is another important impact-related characteristic to buyers seeking to encourage local market development, improve social conditions, or reduce local pollution from fossil fuels. These buyers prefer RECs generated from projects that are as close as possible to the facilities whose demand they are matching (RECS International Secretariat 2018). Buyers typically prioritize on-site generation, followed by sources connected to their same grid, then sources within the same country but on another grid, and finally international purchases (Harrison 2020). Most often, the rules for both compliance and voluntary markets encourage or require such prioritization. Bundling RECs with the underlying electricity serves to demonstrate the proximity of the load and the source. Google and Unilever are two examples of companies that prefer to sign contracts for new renewable generation bundled with RECs and only turn to

\footnotetext{
${ }^{1}$ Additional information on these criteria provided by the Green-e Energy standard, Center for Resource Solutions
} 2019. 
unbundled REC purchases when market or regulatory environments disallow bundled purchases (Google 2016; Unilever 2019).

Yet another important impact-related characteristic is the effect the generation asset may have on the environment. Each customer may have a different opinion regarding the environmental impacts that various assets have. For example, some customers prefer solar and wind projects while avoiding large-scale hydro projects because of concerns over ecological or social disruption of dams, while others may prefer not to procure RECs from biomass projects, which may be associated with local air pollution, land use change, or deforestation (PwC 2016).

\subsection{Benefits to Utilities and the Public Sector}

Utilities and the public sector (e.g., regulators or policymakers) may have many different motivations for offering a REC-based program, including maintaining customer satisfaction, ensuring the financial health of the utility, augmenting budgets for RE development, and potentially achieving policy goals at lower cost. This section describes benefits that utilities may see from offering a REC-based program.

First, a utility may be able to strengthen its financial position by attracting large energy users to locate within its market, while governments can maintain or increase investment from the private sector. It is a growing consideration for corporate RE buyers, especially those that have made RE procurement targets, to consider the availability of RE procurement options as one component of screening criteria for selecting site locations. Corporations may be willing to engage directly with a utility supplier to co-create a new RE product as well, as was the case for the development of the Puget Sound Energy's Green Direct program (Lowder, Logan, and Chen 2019). By attracting new load to their service territory, the utility can secure a long-term electricity customer and support economic development.

Second, depending on the regulatory structure, the utility may also have the opportunity to own renewable projects that serve the REC-based program and earn a return on those investments. At a minimum, REC-based programs typically ensure all of the utility's costs, including administrative and marketing costs, are recovered by the program subscribers, making the utility at least whole for its expenses.

Third, by offering a new program, utilities may see customer satisfaction increase. Studies have shown that customers, even if they are not the ones participating in the programs, have higher satisfaction with their utility when offered an RE program (Mortlock 2019).

Fourth, a REC-based program can help achieve RE or carbon goals at lower cost and with less reliance on taxpayer support by utilizing the private sector's willingness to pay for RE. This area requires some caution and planning to ensure projects are not being double-counted (see Section 2.3); however, it is possible in some markets that a REC-based program would sell RECs to customers while increasing RE capacity and lowering the country's carbon emissions.

These benefits can all be translated from the utility to the public. When utilities draw in new load, for example, they can spread system costs across more ratepayers, thus potentially lowering bills for all customers. Utilities with stronger financial health can also obtain capital at lower 
rates, thus providing a benefit to all consumers. Finally, the public will benefit from seeing RE or carbon goals achieved at lower costs.

\subsection{Framework Components and Stakeholders}

REC-based procurement programs depend on a number of stakeholders and stakeholder-driven components: an enabling policy environment; a tracking system that supports reliable REC generation and trading; and a supply and demand market for RECs. It is important for utilities and other stakeholders to have an understanding of these components and the various partners they may need to engage to ensure that any REC-based programs are aligned with existing policies and laws, and are designed to encourage market uptake. The following sections describe in greater depth each of these components and respective stakeholder groups. Table 2 provides a high-level summary.

Table 2. Summary of REC-Based Program Components

\begin{tabular}{|l|l|l|}
\hline $\begin{array}{l}\text { Program } \\
\text { Component }\end{array}$ & Stakeholder Examples & Purpose \\
\hline $\begin{array}{l}\text { Supportive } \\
\text { Envicy }\end{array}$ & $\begin{array}{l}\text { Energy and environmental } \\
\text { regulators, tax authorities, } \\
\text { market regulators, utilities, } \\
\text { ministries with financial } \\
\text { authority }\end{array}$ & $\begin{array}{l}\text { Provide legal authority; set and } \\
\text { enforce market rules; authorize } \\
\text { utility involvement; stipulate REC } \\
\text { ownership rules; support market } \\
\text { transparency; establish GPPs }\end{array}$ \\
\hline $\begin{array}{l}\text { Tracking } \\
\text { System/Registry }\end{array}$ & $\begin{array}{l}\text { International REC Standard } \\
\text { (I-REC), Tradable } \\
\text { Instrument for Global } \\
\text { Renewables (TIGRs), utility- } \\
\text { operated systems, others. }\end{array}$ & $\begin{array}{l}\text { REC generation, verification, and } \\
\text { trading platform }\end{array}$ \\
\hline $\begin{array}{l}\text { Supply and } \\
\text { Demand Market }\end{array}$ & $\begin{array}{l}\text { RE buyers, RE generation } \\
\text { suppliers, RE goal-setting } \\
\text { programs, marketers, and } \\
\text { brokers }\end{array}$ & $\begin{array}{l}\text { Provide supply and demand for } \\
\text { RECs; facilitate REC trading }\end{array}$ \\
\hline
\end{tabular}

\subsubsection{Supportive Policies and Regulations}

There are several key policy, regulatory, and legal frameworks that must be in place and clearly implemented to support robust REC markets, including enabling mechanisms, ownership rights, data access, and the ability to procure third-party REC tracking systems or auditing services. Once a supporting structure of rules is in place, utilities or governments can choose to establish GPPs that incorporate RECs.

First and foremost, government policies and regulations must support the existence, function, and enforcement of the mechanisms involved with REC generation and sale. Without these enabling policies, even if demand exists, RE generators or buyers may not have the authority, ability, or market confidence needed to buy and sell RECs. Although the procedures and parties 
responsible for implementing policies and laws vary from market to market, essential rules include those that:

- Allow for REC contracts

- Support nontraditional revenue generation by utilities

- Define relevant tax considerations

- Provide for a legal system that can equitably settle disputes.

Further, clear frameworks and rules for the ownership of RECs must be established. Electricity markets often involve RE generation by independent power producers (IPPs) through PPAs with utilities. The PPA contracts (or other established overarching laws) must clearly describe who has ownership rights to the RE attributes. In many instances, older laws are silent on this point, so PPA templates or contracts may need to be updated to avoid legal challenges that could undermine the ability to verify REC ownership and establish credibility.

In addition, data access for energy generation is central to being able to verify the quantity and uniqueness of the RE represented by a REC. Laws and policies must allow for the potential for third-party verifiers to routinely view generation data, and in some instances, physically inspect generation and metering devices; this may introduce challenges for some utilities.

In instances where expertise is not available, establishing REC tracking systems may require laws that allow international firms to provide technical services or sell subscription-based access to their products. A typical means for granting local access to international firms in some markets is to have the provider establish an in-country office; however, when REC programs are first starting, there are usually fewer transactions, thus making it difficult for the provider to have sufficient revenue to establish an in-country office right away. Procurement laws that allow for flexibility in hiring international firms could open the market to the range of market expertise.

For all of these supporting policies, the market uncertainty that can result from insufficient implementation or frequent changes reduces market confidence in REC-based products. This uncertainty increases buyers' risks and results in lower REC valuation. Clear, consistent, and fair policies allow buyers to establish solid plans without concern for radical shifts in policy or legal jeopardy (see Text Box 1).

\section{Text Box. 1. Mexico's REC Program}

In Mexico, the government's Comisión Reguladora de Energía issues RECs, which are the Mexican government's main instruments to achieve national clean energy generation goals. Some energy market actors are obligated to procure RECs, including all electricity suppliers and some electricity customers with loads greater than $1 \mathrm{MW}$. These "Obligated Participants" must meet RPS requirements such that a minimum percentage of the electricity they generate, sell, or buy is certified as renewable. Participants' RE obligations will increase from 5\% in 2018 to $13.9 \%$ in 2022 .

If a participant has not contracted directly with an RE generator to purchase enough bundled RECs to meet their obligations, they must buy unbundled RECs separately from any electricity 
procurement. RECs are traded on the REC market, which is operated by the same agency that runs the wholesale electricity market. Comisión Reguladora de Energía keeps track of all transactions, and REC prices fluctuate based on supply and demand. Some market actors (such as customers with loads under $1 \mathrm{MW}$ ) are not obligated, but still can register as "voluntary participants" with Comisión Reguladora de Energía and buy RECs on the market.

The REC regime was established as part of Mexico's 2014 energy sector-wide reforms to encourage additionality. As such, only MWhs generated by an RE system built after August 11, 2014, could be certified as a REC; however, in November 2019 the government announced it would certify RECs from aging hydropower dams held by the government-owned utility, CFE. Doing so would flood the market in 2020 with nearly three times as many new RECs as were demanded in all of 2019. The value of Mexico's RECs could plummet from the 2019 range of USD \$15-25 per REC, to being of negligible value (Castro, Ellis, and Nelson 2020). As a result, multiple RE generation companies sued the Mexican government, and in late November 2019, a Mexican court issued an injunction blocking the policy indefinitely.

\subsubsection{Tracking Systems}

REC tracking systems are electronic accounting platforms that can be owned and operated by private companies, nonprofit organizations, government entities, or utilities. ${ }^{2}$ Tracking systems $^{2}$ may be established and operated under their own rules and procedures, but they typically follow or directly adopt core principles and mechanisms developed by international stakeholder groups to provide market confidence in the RECs under their purview. Without standardized procedures and the transparency expected by the market, REC values can be diminished (CDP 2020).

RE project owners register RE generation assets with REC tracking systems through contracts, providing information regarding the RE type, ownership, size, location, and age of the equipment. Registered asset owners provide auditable generation data for the electricity produced to the tracking system, connecting that data with the generation asset. RECs are created in the tracking system on a MWh basis, which the asset owner can transfer to another entity via a sale or other contractual arrangement. Alternatively, the owner may retire the RECs themselves to satisfy their own RE commitment needs. All transfers of ownership and the ultimate retirement of each REC is documented in the tracking system. Figure 5 depicts this process.

\footnotetext{
${ }^{2}$ Concerns over conflict of interest require utilities to avoid verifying their own RECs or to separate generation and verification with a firewall.
} 


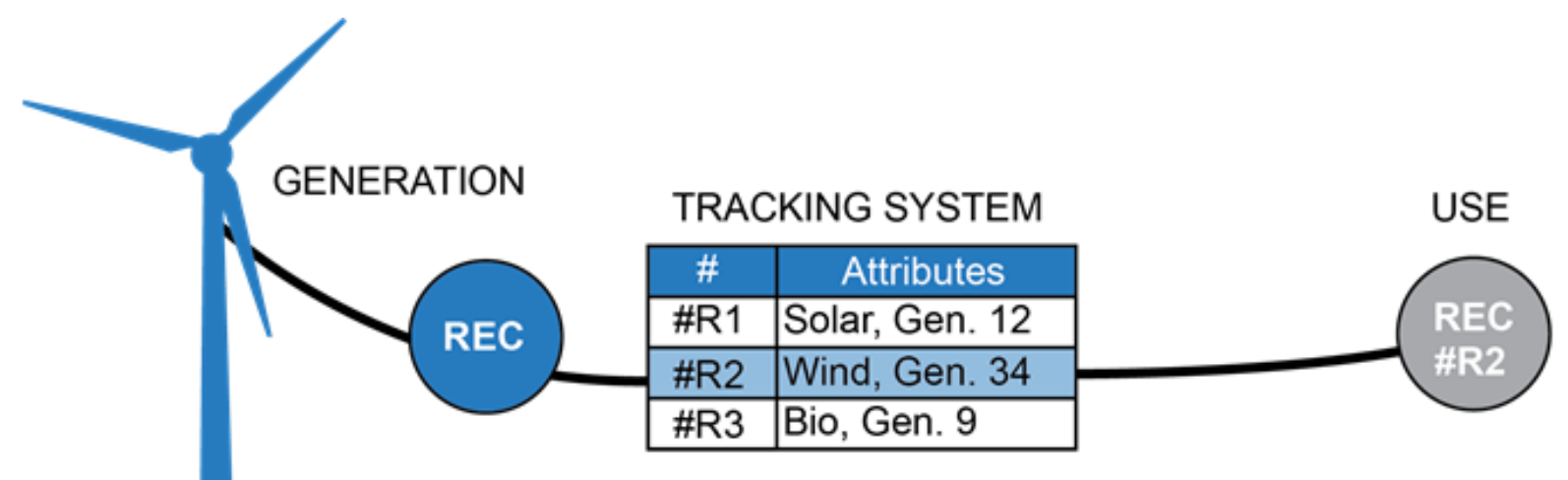

1 MWh of RE output generates a REC
REC is registered in a REC tracking system, assigned unique ID\#
REC is retired on behalf

of an RE customer

Figure 5. REC tracking system process

Note: attribute values shown are examples only

An essential component of a REC tracking system is the verification of the RE generator and generation data. When an asset owner first registers a project, tracking system operators verify the source characteristics, paying particular attention to any claims to REC ownership that may exist in PPAs or other legal documents. This is done to avoid conflicting claims to REC ownership, which would reduce or negate REC value and tracking system credibility.

For generation data, the tracking system typically relies heavily on meter data or documentation provided by the asset owner, and utilizes third-party verifiers, or qualified reporting entities (QREs) to assess questionable data and spot check across its portfolio of registered projects. QREs must be vetted but can be the grid operator, regulator, or utility if the asset is not utilityowned (see Text Box 2). Once the QRE approves of the requested REC quantities, they upload the formatted data to the REC registry, which conducts an automatic assessment of weather and other data to verify the feasibility of the requested REC volume. Once these checks pass, the RECs are verified and issued (APX 2018). Tracking systems maintain a documentation trail throughout all ownership transfers that may occur until retirement, but they are not involved with the sale of RECs to customers.

REC tracking systems and RE stakeholders continue to innovate around the technologies used to certify and trade RECs. One such area of recent interest is the integration of blockchain technologies into REC tracking systems to facilitate rapid and reliable generation data verification, protect data, and reduce transaction costs (Sindicatum 2019). 


\section{Text Box 2. Malaysia Establishing a REC Platform}

Although the Malaysian energy market is highly regulated and vertically integrated, the Ministry of Energy, Science, Technology, Environment and Climate Change is studying the potential of granting corporations more flexibility in purchasing clean energy through market liberalization. Malaysia's Sustainable Energy Development Authority (SEDA) has partnered with APX to integrate Malaysian RECs using APX's TIGRs registry. SEDA will operate as the QRE to verify generator data. Generators looking to certify their RECs will submit meter data to SEDA, which will perform preliminary verification before submitting data to the TIGRs registry. Once APX validates the generator data (such as determining the technical resource feasibility of the metered generation), the RECs will be created. In general, RE generators in Malaysia with over $20 \mathrm{MW}$ of nameplate capacity can expect to pay around $\$ 1,000$ as an annual fee to register RECS on the TIGRs registry, plus a per-REC issuance fee charged by APX and a verification fee charged by SEDA.

Two existing REC tracking systems with extensive international experience include the TIGRs system operated by APX, and the I-REC Standard developed by the nonprofit organization of the same name. The TIGRs tracking system supports REC issuance and tracking in 10 countries, including Vietnam, China, the Philippines, Malaysia, India, and Guatemala (APX 2019). The IREC standard is currently being implemented in 25 countries, including Mexico, Colombia, Indonesia, Vietnam, and the Philippines.

\subsubsection{REC Marketplace}

A REC marketplace is any venue that supports REC trading between buyers and sellers. Marketplaces serve both voluntary and compliance regimes to facilitate transparent and trustworthy sales to optimize transaction costs and reduce risks while meeting the needs of both buyers and sellers. Market participants in voluntary markets can include RE generation suppliers (such as utilities, IPPs, project developers, and even residential system owners), private sector buyers, marketers, and brokers. In compliance markets, buyers may additionally include electricity generators, distribution companies, and others that have statutory RE quota requirements.

REC marketplaces utilize a range of mechanisms to perform transactions, including relatively simple direct contracts between participants, electronic "bulletin boards" and brokerages that facilitate matchmaking, and auctions. Direct contracts are built on relationships between buyers and sellers, such as between a utility and an industrial customer or between an IPP and a utility. These direct transactions may be performed via REC sales web portals or direct communications between parties. Bulletin boards and brokered deals connect buyers and sellers who may not be acquainted to enter into negotiated contracts. Auctions serve to connect buyers and sellers that mutually agree on pre-negotiated contract terms. GPPs themselves form a sort of marketplace by connecting REC suppliers (i.e., utilities and sometimes governments) and buyers through shortterm green pricing and long-term green tariff contracts. 
REC marketers and brokers are participants that facilitate REC trades. Marketers serve as an intermediary by buying and selling RECs, taking ownership of the REC in the process but never making a claim to the RE attributes. Brokers, on the other hand, simply connect buyers and sellers without taking any ownership. Both marketers and brokers typically charge a premium for their services. These types of transactions are generally short term with more fluid pricing and are directly impacted by the immediate supply and demand of RECs on the market. As with any market, the more activity and transparency, the more competition that is created, which can improve customer choice and lower costs. These dynamics are discussed in greater detail in Text Box 3.

\section{Text Box 3. Expert's Perspective: Market Competition is Key (by Jared Braslawsky, I- REC Standard Foundation)}

REC markets can accelerate the deployment of renewable power generation by facilitating and harnessing customer demand. These markets allow end users to choose where to get their electricity from, be it a local wind farm or a large solar plant in another country. End users are thus empowered to choose products that are good for their organization, the environment, and the electricity market as a whole. The strength of these markets is the competition they create. Competition between fossil or renewable power, competition between renewables, such as solar, wind or hydro; competition on sustainability, whether large hydro or small solar; and competition on the age of the generating plant. Each of these elements influences end users' choices and what they will pay to claim the use of a given product. Their choice is a vote with their wallets for the type of electricity linked to the certificate they buy. This choice differentiates REC markets from the wider electricity market. Certificates, as a product, are unique and can be highly specified. Electricity, as a commodity, has the same properties wherever it is generated or used.

This is why successful REC markets around the world allow for a diverse range of participants and are governed by different rules than those applied to electricity markets. For example, only allowing a single seller of RECs in a country could create a pay-to-play market where the seller controls volumes and prices. This would negate a key aspect of REC marketsharnessing customer demand to create competition between electricity generators. It would also block the vital market signals that can be used to accelerate the energy transition while reducing the burden on support schemes. No voluntary REC market has been successful where there is a single government-mandated seller; a situation that is unlikely to change in the future.

\subsection{Additional Considerations: Interactions with Feed-In Tariffs, Carbon Accounting and Markets, and National GHG Inventories}

RECs have the potential of interacting with other government and market programs aimed at GHG reductions or increasing RE deployment, such as feed-in tariffs (FIT), carbon accounting, and national GHG inventories. It is important to carefully coordinate related activities to avoid double-counting, disjointed planning, or conflicting program goals. 
A FIT is a tool used by policymakers to incentivize RE project development by IPPs or other project investors by providing payment to project owners for electricity fed into the grid, and often granting priority grid access and dispatch. There are a number of approaches to REC ownership under FIT regimes, ranging between full REC ownership granted to the project developer to full ownership granted to the utility. Options within this ownership range could include sharing RECs or profits between the utility and project developer based on project profitability. An additional option, described in Text Box 4, transfers REC ownership to a government entity for use in RE development mechanisms.

Each FIT approach has implications that policymakers should consider, keeping in mind the overarching purpose of RECs as an incentive for RE development. Under structures that grant RECs to utilities or the government, if FITs are set at low levels that only marginally incentivize project development, taking potential REC revenue from developers may discourage private sector investment in RE projects. Conversely, where REC ownership is fully granted to project developers, high FITs and foregone REC revenue may strain public financial resources. Ultimately, there can be a balance between REC ownership and FIT levels that encourages private sector investment while conserving public sector resources. As previously noted, regardless of how RECs are dealt with under a FIT scheme, laws and contract language must be clear to avoid legal conflicts.

\section{Text Box 4. REC Interaction with Japan's FIT}

Japan's electricity market was historically composed of a monopoly of 10 regional utilities, but a series of liberalizations took place in the 2000 s, resulting in a competitive wholesale market and utility choice for most customers. Japan has national RE targets, including an RPS. As an island nation vulnerable to volatile global fossil fuel prices, it has prioritized self-sufficiency of energy production. To meet these goals, Japan has implemented a FIT to encourage RE development (Harrison 2020). Since the FIT is funded by ratepayer subsidies to incentivize the public benefits of RE, the government has decided that the resulting RECs do not belong to the FIT generator, and are instead sold through a series of auctions hosted by the Japan Electric Power Exchange (JPEX). Corporations in Japan - 30 of which have joined RE100 - have the option to purchase RECs via the JPEX. In some situations, corporations purchase RE through a PPA as a price arbitrage without bundling the energy with RECs, and then purchase the associated RECs over the JPEX. Other purchasers of FIT RECs include utilities, who bundle the RECs with electricity to offer green pricing products or green tariffs, which are another option for renewable-seeking corporations (Takase, Ishida, and Telang 2020).

Another important interaction that should be considered is how to account for grid emissions factors in voluntary corporate reporting or utility reporting if there is a proliferation of RECs in a given market. Grid emissions factors are based on the mix of generation sources on the grid and are used to estimate GHG emissions for a range of reporting purposes, including national-level inventories, utility targets and progress, and end users' emissions from purchased electricity for various voluntary reporting programs. When renewables are added to the grid, the tons of carbon dioxide equivalent $\left(\mathrm{tCO}_{2} \mathrm{e}\right)$ per $\mathrm{kWh}$ decreases; however, since the benefits of $\mathrm{RE}$ belong to the 
REC owner, other recipients of electricity from the grid should not be able to make claims that take advantage of those RECs through their application of emissions factors. WRI's GHG Protocol Scope 2 Guidance describes how emissions factors should be adjusted accordingly, based on the end use of the emissions calculations, to avoid double-claiming (Sotos 2015). Though to-date voluntary purchases may not substantially impact emissions rates, this is an issue that will become more prominent as voluntary purchases increase.

RECs and carbon accounting are closely related in that implementation of RE projects can reduce GHG emissions when compared to business as usual or when fossil fuel-based power sources are replaced with renewables. Carbon markets monetize carbon credits in much the same way that REC markets monetize RE, relying on demand from voluntary or compulsory reduction goals. Various carbon markets have rules that allow for conversion of RE generation ( $\mathrm{kWh}$ ) from certain sources to $\mathrm{GHG}$ credits $\left(\mathrm{tCO}_{2} \mathrm{e}\right)(\mathrm{CRS} 2012)$. However, these rules do not allow for a given $\mathrm{kWh}$ of renewables to be sold as both a REC and a carbon credit. Further, the qualifying rules for carbon credits are typically more stringent than for RECs, particularly when it comes to additionality. ${ }^{3}$ Consequently, it is important to coordinate the rules between REC and carbon programs to ensure that no double-counting occurs and that ineligible sources are handled appropriately.

National-level GHG reduction commitments, such as those made under the Paris Climate Agreement, are generally treated separately from REC and carbon markets. ${ }^{4}$ National-level inventories assess GHG emissions produced ("sources") and sequestered ("sinks") within a country's borders and compare changes on an annual basis to a baseline or business-as-usual projections. RECs are not needed to confirm the project-level RE generation that may translate to GHG reductions in a national inventory. Instead, national emissions are determined by using estimation techniques, including using utility energy production data in conjunction with emissions factor estimates. National inventories are calculated independently of asset ownership, while corporate inventories seek to assign emissions to specific market participants.

Accordingly, there is no concern with double-counting reduction claims at the national-level and project-level RE.

\footnotetext{
${ }^{3}$ Additionality refers to projects that would not have occurred without market incentives.

${ }^{4}$ Under Article 6 of the Paris Agreement, negotiators are seeking to develop an international carbon trading mechanism that may involve provisions to avoid double counting of emissions credits (Kizzier, Levin, and Rambharos 2019).
} 


\section{REC-Based Program Implementation Options}

The flexible applicability of RECs allows utilities and regulators to design REC-based RE procurement programs in a variety of ways and to be involved in program management to varying degrees. The sections below describe the design and engagement options. Appendix provides a framework for assessing these options and the key milestones on the path to program initiation.

\subsection{Program Design}

The programs utilities can use to sell RECs include direct sales of unbundled RECs and GPPs. Where supported by law, private-sector project owners can also sell RECs through third-party PPAs or leases. These options are detailed in Table 3 and discussed in further detail in the following sections. In all cases, buyers demand that RECs be registered, tracked, and retired through a third-party or utility-managed tracking system. 
Table 3. Program Options Utilizing RECs

\begin{tabular}{|c|c|}
\hline $\begin{array}{l}\text { RECs Offered } \\
\text { Through.... }\end{array}$ & Option Description \\
\hline $\begin{array}{l}\text { Unbundled REC } \\
\text { Sales }\end{array}$ & $\begin{array}{l}\text { Utilities generate RECs from their own RE projects or through on-grid } \\
\text { PPA contracts with IPPs. The utility sells RECs separately from } \\
\text { electricity ("unbundled") to customers through marketers or brokers or } \\
\text { direct agreements with corporate buyers. Unbundled REC sales are } \\
\text { the most flexible mechanism, as they are not tied to electricity } \\
\text { purchases or location. In large markets, unbundled RECs may offer a } \\
\text { cost-competitive option as corporations can take advantage of the } \\
\text { most efficient projects (e.g., in the United States, many unbundled } \\
\text { RECs come from large wind farms in Texas that are far from load } \\
\text { centers); however, unbundled RECs are typically the least desirable to } \\
\text { corporations given the challenges of communicating impacts to } \\
\text { customers and investors.. }\end{array}$ \\
\hline Green Pricing & $\begin{array}{l}\text { Utilities sell RECs as an add-on to a customer's standard electricity bill } \\
\text { at a price premium through short term (e.g., monthly) purchase } \\
\text { agreements; utilities may obtain RECs separately from their own } \\
\text { generation sources; and the utility stipulates the RE source type. A } \\
\text { green pricing line item is added to the customer's bill to account for the } \\
\text { cost of the REC and program operating costs. Prices fluctuate with } \\
\text { electricity prices and do not offer a cost savings to the customer. This } \\
\text { is the second most flexible option and may appeal especially to } \\
\text { corporations with leased space and/or shorter market investment } \\
\text { horizons who are not able to sign long-term contracts and who may not } \\
\text { have electricity cost savings as a primary driver. }\end{array}$ \\
\hline Green Tariffs & $\begin{array}{l}\text { Utilities sell RECs bundled with electricity from specific projects, } \\
\text { usually through long-term contracts with major customers. The utility } \\
\text { obtains RE through its own projects or via IPPs and then negotiates a } \\
\text { price with the customer. The buyers may retire or resell the RECs. } \\
\text { Contracts can be structured to provide long-term price stability and } \\
\text { cost savings to customers and long-term RE project financing sources } \\
\text { for RE project developers. }\end{array}$ \\
\hline $\begin{array}{l}\text { Third-Party } \\
\text { PPA/Lease } \\
\text { Between } \\
\text { Developer and } \\
\text { End User }\end{array}$ & $\begin{array}{l}\text { In more liberalized markets, bundled RECs can be generated by an on- } \\
\text { or off-site contract with IPPs or other project developers and sold } \\
\text { directly to end users; unbundled RECs may be sold on the open } \\
\text { market. The utility is not involved with the REC transactions but may } \\
\text { receive a wheeling fee. }\end{array}$ \\
\hline
\end{tabular}




\subsubsection{Direct Unbundled REC Sales}

The most straightforward way for a utility to provide RECs to its customers is through direct sales of RECs unbundled from the underlying electricity. The RECs that a utility may have on offer could come from either RE generation that it owns and operates or from IPPs that it contracts with to feed RE to the grid. Utility-owned generation offers straightforward access to the associated RECs and requires only registration in a tracking system. As previously noted, IPP-generated RE can introduce ownership-related questions that must be resolved through PPA or other legal declarations; this is especially true for any legacy PPA contracts with IPPs.

Whether RECs are owned by the utility or an IPP, they may be sold directly to customers once they have been registered in a REC tracking system. Direct REC sales can be arranged through contracts between the utility (or IPP) and the buyer and may take a number of forms. Examples of variations that can underpin a contract include: short- or long-time horizons, generatorspecific or aggregated generation pools, and fixed or market-pegged pricing. Another sales option is to utilize brokers and marketers to facilitate trades, as described in Section 2.2.3. Utility and corporate buyer perspectives related to direct unbundled REC sales are summarized in Table 4 .

Table 4. Stakeholder Perspectives on Direct Sales

\begin{tabular}{|c|c|}
\hline Utility Perspective & Corporate Buyer Perspective \\
\hline $\begin{array}{l}\text { For utilities, direct REC sales offer a low- } \\
\text { investment option for offering RECs to } \\
\text { customers as they avoid the need to design } \\
\text { and manage other procurement programs } \\
\text { that incorporate RECs; however, direct sales } \\
\text { do not readily provide utilities with } \\
\text { opportunities to add product features that } \\
\text { may encourage corporate purchases. Direct } \\
\text { sales can be set up relatively easily, and most } \\
\text { of the steps needed for implementation, such } \\
\text { as project registration, are also needed for } \\
\text { other procurement programs, so can serve as } \\
\text { a stepping stone toward more robust } \\
\text { programs or even a compliance program } \\
\text { such as an RPS. }\end{array}$ & $\begin{array}{l}\text { Direct REC sales offer corporate buyers } \\
\text { opportunities for short-term and small volume } \\
\text { RE purchases; however, buyers may have to } \\
\text { commit time and resources on a recurring } \\
\text { basis to identify and procure RECs that meet } \\
\text { their needs if they are not able to purchase } \\
\text { them through a longer-term contract. }\end{array}$ \\
\hline
\end{tabular}

\subsubsection{Green Pricing}

Utility green pricing programs involve the utility retiring RECs on behalf of the subscribed customer's participation. Green pricing subscribers generally pay an additional line item on their bill, which contains the cost of the RECs, in addition to any administrative or program operating costs. ${ }^{5}$ Subscribers typically only commit to purchasing on a monthly basis, and can cancel their

\footnotetext{
${ }^{5}$ In some designs, utilities have also exempted subscribers from paying fossil fuel charges on their existing bill, which lowers the net cost of the subscription.
} 
participation without incurring a fee. Program participants in green pricing programs typically do not dictate the sources of renewable electricity provided by the utility, although the utility may voluntarily disclose this information as part of a verification program, as well as in their program marketing materials and news releases. ${ }^{6}$ The utility can bundle RECs from existing renewable generators, generate RECs by developing or procuring new renewable capacity, or by purchasing RECs from nonutility generators within the same market as the utility.

As opposed to direct REC sales, green pricing programs offer utilities more opportunity to design a product that is appealing to buyers as a means to increase sales and support RE development. Features that allow companies to easily access and manage the RE procurement that meets their needs will draw more customers (see Text Box 5). Such features could include flexible RE source selection, competitive pricing, attractive contracting terms, and ease of use (for example, online purchases or integration with bills). The perspectives on green pricing mechanisms from the utility and corporate buyer perspectives are highlighted in Table 5.

\section{Text Box 5. Green Pricing Example from Europe}

Many European countries use the Guarantees of Origin (GO) — one of several tracking systems used in Europe to provide customer confidence in RE purchases. ${ }^{7}$ Utilities in Europe commonly trade GOs - which are roughly equivalent to RECs - to allow subscribers to claim RE consumption through green pricing programs. The European Union has standardized GOs and provides regulatory oversight of green pricing programs in Europe. GOs also provide customers with specific details of the sources of electricity in their green pricing program. Product transparency allows customers to choose products that are most relevant to them. For example, a European corporate customer might choose a green pricing program offering nearby solar capacity over one offering hydroelectric GOs from another country, even if the latter is at a lower cost. A recent development in the European GO market involves the European Parliament's decision to allow corporations to purchase GOs directly from renewable generators (up to this point, GOs have primarily been available bundled as part of a green pricing program). Additionally, generators that are receiving a subsidy which specifically implies the sale of both electricity and renewable attributes to the grid-such as FIT programs — do not receive GOs.

Table 5. Stakeholder Perspectives on Green Pricing

\begin{tabular}{|c|c|}
\hline Utility Perspective & Corporate Buyer Perspective \\
\hline $\begin{array}{l}\text { Utilities offering green pricing can recover } \\
\text { program costs, so should not entail long-term } \\
\text { deficits. One challenge utilities may have is } \\
\text { ensuring that customers are aware of the }\end{array}$ & $\begin{array}{l}\text { Green pricing products, because of their } \\
\text { short-term subscription and price premium, } \\
\text { tend to be favored by residential and small- to } \\
\text { medium-sized companies without large load. }\end{array}$ \\
\hline
\end{tabular}

${ }^{6} \mathrm{~A}$ disclosure statement is required if the utility program is Green-e Energy certified.

${ }^{7}$ An alternative European tracking scheme is EKOenergy. https://www.ekoenergy.org/. 
program, which requires marketing campaigns to ensure participation. However, these programs offer utilities a product to engage new customers and increase sales to existing ones.
Green pricing products may also be attractive to companies that are leasing space and those unable to make long-term commitments to be in a particular market. Larger companies may be better able to leverage their buying power to find more cost-effective products such as green tariffs.

\subsubsection{Green Tariffs}

Green tariff programs are long-term contracts that provide buyers with price stability in exchange for a commitment to procure for extended time periods. Green tariff programs are often geared toward larger customers with higher loads (see Text Box 6). Contracts can be agreed to at any stage of RE project development or operation; however, long-term preconstruction contracts can serve to incentivize project development by providing early and stable commitments of an additional revenue stream to the project on top of power sales, helping to solidify project economics.

\section{Text Box 6. U.S. Green Tariff}

Green tariffs are a popular option for large corporations working to meet voluntary renewable targets. A number of large tech companies, including Apple in Nevada and Google in North Carolina, have signed contracts with utilities through green tariff programs (EPA 2018). In some cases, companies have even worked with utilities and regulators to establish green tariff programs when programs did not exist. Companies are particularly drawn to green tariff programs when the new renewable generation cost replaces the generation charge on the customer bill. Because the levelized cost of RE is declining below the cost of fossil fuel generation, green tariffs can offer RE at a similar cost to utility bill generation charges if corporations are able to sign long-term agreements. As of 2018, some 3.3 million MWh of electricity was sold through green tariff programs accounting for roughly $2.5 \%$ of all voluntary RE purchases in the United States (Heeter and O'Shaughnessy 2019)

Bundled RECs generated by the RE resource can be tracked in a REC registry and retired on behalf of customers. Green tariffs have been made available in regulated markets often at the behest of large corporations that have been willing to undertake bilateral negotiations with utilities; this may result in new mechanisms that can then be available to additional customers.

For green tariff programs, the generation charge for the existing tariff is often replaced by the new cost of renewable generation (such as a PPA contract price) and may include administrative charges passed on by the utility. Most common is the replacement or decrease of fuel surcharges, energy costs, or power cost adjustments. In these cases, the green tariff program charge also 
provides long-term price certainty against changing fuel and energy costs. Table 6 provides stakeholder perspectives regarding green tariffs.

Table 6. Stakeholder Perspectives on Green Tariffs

\begin{tabular}{|l|l|}
\hline Utility Perspective & Corporate Buyer Perspective \\
\hline $\begin{array}{l}\text { In the United States, utilities in some cases } \\
\text { have created green tariffs to draw new load to } \\
\text { their service territory, which allows them to } \\
\text { earn greater profits. In addition to gaining new }\end{array}$ & $\begin{array}{l}\text { Green tariffs, which typically require long-term } \\
\text { commitments, are favored by companies that } \\
\text { load, utilities recover their administrative } \\
\text { costs. }\end{array}$ \\
$\begin{array}{l}\text { and will be located in the same utility service } \\
\text { territory for the length of the commitment. }\end{array}$ \\
\hline
\end{tabular}

\subsubsection{Third-Party PPAs}

Where allowed by law, third-party PPAs allow customers to purchase their electricity directly from an RE project developer rather than the electric utility, through either on- or off-site agreements with end users. On-site contracts, which may take the form of leases, deliver RE and RECs directly to corporate loads. Utilities are typically uninvolved unless excess electricity is fed to the grid through a FIT mechanism, but Text Box 7 demonstrates the range of implementation options with a unique approach.

\section{Text Box 7. Philippines Third-Party PPAs}

The Philippines Department of Energy is taking steps to provide corporations easier access to generation from renewable plants. The new Green Energy Option Program (GEOP) will allow customers with a monthly peak demand averaging over $100 \mathrm{~kW}$ to independently source their generation. Corporations will be able to sign a PPA with a renewable-based generator. The customer will continue to pay wheeling charges to their utility, which include distribution and transmission costs, but will pay the RE project owner for generation. The GEOP is currently being finalized, and corporations are beginning to express interest. While the GEOP provides corporations with the ability to source their own electricity, the policy provides the utility with all RECs associated with renewable electricity generated as a means of utility compliance with the RPS. Because the RECs are not granted to the customer participating in the GEOP, a corporate customer must procure replacement RECs to be able to make a claim of using RE. To facilitate these trades, a new REC marketplace is being developed on top of the country's existing wholesale energy market.

Under off-site PPAs, the third-party owned RE project effectively provides supply to the customer, while the utility continues to provide transmission, distribution, and balancing services. The IPP will likely pay a "wheeling charge" for use of the utility's transmission infrastructure (Heeter et al. 2016). Because the electrons being delivered to the customer are not the exact ones being injected by the RE project, the utility needs to agree on a balancing 
arrangement with the customer. This agreement establishes the frequency that IPP generation and customer demand are equal (i.e., hourly, daily, weekly).

Where third-party RE sales are allowed, the utility may lose out on revenue from the sale of electricity generation; however, in markets with rapidly growing electricity consumption, reducing large corporate loads through on-site projects can meaningfully reduce a utility's shortterm capacity needs. Additionally, for off-site projects, wheeling charges ensure that the utility is able to recover costs for the services it continues to provide, namely transmission, distribution, and balancing. Table 7 highlights stakeholder perspectives on third-party PPAs and leases.

Table 7. Stakeholder Perspectives on Third-Party PPAs/Leases

\begin{tabular}{|c|c|}
\hline Utility Perspective & Corporate Buyer Perspective \\
\hline $\begin{array}{l}\text { Third-party PPAs and leases take away } \\
\text { generation services from the incumbent utility, } \\
\text { and, therefore, utilities may be reluctant to } \\
\text { agree to the structure, particularly if it might } \\
\text { result in lower cost recovery on their existing } \\
\text { plant investments. The utility would still } \\
\text { provide transmission and distribution and } \\
\text { recover costs for those services. }\end{array}$ & $\begin{array}{l}\text { IPPs may be interested in third-party PPAs or } \\
\text { leases because it allows them to supply } \\
\text { directly to customers, rather than needing to } \\
\text { work through the utility. These arrangements } \\
\text { may also create a larger pool of customers } \\
\text { than a green pricing program or green tariff. } \\
\text { Some stakeholders have argued that third- } \\
\text { party PPAs or leases provide more } \\
\text { competition to provide generation, and, thus, } \\
\text { can create lower prices for customers. }\end{array}$ \\
\hline
\end{tabular}

\subsection{Options for Managing RECs}

Utilities and regulators have a range of options for their role in a REC-based program for corporate RE procurement. These options range from simple registration of RECs from their own projects to the more complex establishment of a utility-operated tracking system integrated with a GPP. In between these two are a mix of options that can be selected to meet utility needs and market contexts. These options could be implemented in a stepwise fashion, from the least to the most complex, in such a way as to minimize upfront costs and incrementally build utility capabilities and expertise toward full tracking system ownership and operation. The respective pros and cons of the options are described from the utility perspective in more detail in Table 8 . 
Table 8. Options for Utility Involvement in REC Management

\begin{tabular}{|c|c|c|c|}
\hline $\begin{array}{l}\text { Utility } \\
\text { Involvement } \\
\text { Option }\end{array}$ & Description & Pros & Cons \\
\hline \multirow[t]{3}{*}{$\begin{array}{l}\text { Utilize an } \\
\text { existing REC } \\
\text { registry and } \\
\text { its rules }\end{array}$} & \multirow[t]{3}{*}{$\begin{array}{l}\text { Utility uses an existing REC } \\
\text { tracking system and its } \\
\text { rules to register, track, and } \\
\text { retire RECs; sell RECs on } \\
\text { the market or through } \\
\text { contracts }\end{array}$} & $\begin{array}{l}\text { Simple and } \\
\text { inexpensive way to } \\
\text { ensure RE meets } \\
\text { customer needs } \\
\text { and international } \\
\text { best practices }\end{array}$ & $\begin{array}{l}\text { Limited control of } \\
\text { REC product } \\
\text { characteristics }\end{array}$ \\
\hline & & $\begin{array}{l}\text { The utility could } \\
\text { pilot test multiple } \\
\text { registries }\end{array}$ & $\begin{array}{l}\text { Limited hands-on } \\
\text { involvement of } \\
\text { REC management }\end{array}$ \\
\hline & & $\begin{array}{l}\text { The utility gains } \\
\text { experience } \\
\text { registering projects } \\
\text { and selling RECs }\end{array}$ & $\begin{array}{l}\text { Limited ability to } \\
\text { build capacity for } \\
\text { REC management }\end{array}$ \\
\hline \multirow[t]{3}{*}{$\begin{array}{l}\text { Establish } \\
\text { utility-owned } \\
\text { registry }\end{array}$} & \multirow{3}{*}{$\begin{array}{l}\text { Utility establishes } \\
\text { databases, protocols, rules, } \\
\text { secure platforms, } \\
\text { validation, and so on to } \\
\text { register, track, and retire } \\
\text { RECs; sell RECs on the } \\
\text { market, through business- } \\
\text { to-business contracts, or } \\
\text { with green procurement } \\
\text { products }\end{array}$} & $\begin{array}{l}\text { Full control of REC } \\
\text { system design and } \\
\text { operation }\end{array}$ & $\begin{array}{l}\text { Highest upfront } \\
\text { cost }\end{array}$ \\
\hline & & $\begin{array}{l}\text { Potential cost } \\
\text { savings/revenue } \\
\text { gains in the long } \\
\text { run }\end{array}$ & \multirow{2}{*}{$\begin{array}{l}\text { Requires utility to } \\
\text { develop deep } \\
\text { technical capacity } \\
\text { and maintain } \\
\text { compliant operating } \\
\text { systems }\end{array}$} \\
\hline & & $\begin{array}{l}\text { Flexibility for } \\
\text { system design and } \\
\text { pricing }\end{array}$ & \\
\hline $\begin{array}{l}\text { Establish a } \\
\text { hybrid system } \\
\text { with some } \\
\text { REC } \\
\text { management } \\
\text { performed by } \\
\text { the utility and } \\
\text { some by } \\
\text { other } \\
\text { stakeholders }\end{array}$ & $\begin{array}{l}\text { There are multiple } \\
\text { implementation scenarios } \\
\text { that allow varying levels of } \\
\text { utility involvement; sell } \\
\text { RECs on the market, } \\
\text { through business-to- } \\
\text { business contracts, or with } \\
\text { green procurement } \\
\text { products }\end{array}$ & $\begin{array}{l}\text { Allows for flexible } \\
\text { implementation to } \\
\text { fit a given context } \\
\text { while maintaining } \\
\text { access to tracking } \\
\text { system expertise } \\
\text { and tools. }\end{array}$ & $\begin{array}{l}\text { More costly than } \\
\text { fully utilizing } \\
\text { existing systems }\end{array}$ \\
\hline
\end{tabular}

\subsubsection{REC Registration Through Established Registries}

Utilities can engage existing tracking systems to register their RE projects and subsequently offer the RECs for sale to customers via marketers, brokers, or direct contracts with customers. This 
approach offers utilities a relatively simple and inexpensive way to participate in the REC market. By leveraging established protocols, utilities can ensure that the RECs they are producing meet the international standards that buyers demand without the need to expend utility resources on staffing, designing, and implementing a tracking system themselves.

The existing rules and procedures used by tracking systems have been developed with broad input from a range of international stakeholders and are vetted and tested over many years. They are widely trusted by the market, so the resulting RECs have an inherent demand. This facilitates product marketing because it comes with known and trusted branding that would otherwise need to be done by the utility.

Using an existing REC tracking system can give a utility firsthand experience with the various steps of the process, such as REC registration and verification. Afterward, going through the sales process offers experience with the sales market, establishes contacts that can facilitate future sales, and provides direct experience with REC pricing and market demand. These invaluable experiences can help guide a utility's thinking on future program designs and goals. Some of the key design considerations are highlighted in Text Box 8.

\section{Text Box 8: GPP Advice from APX (by Lars Kvale, APX)}

When designing green programs, it is important for utilities to take into account the objectives of the program and preferences of potential customers. Key questions include:

1) Customer type: Will the customers primarily be large corporate and industrial buyers, or instead small businesses and households? Purchasers of large volumes generally require more disclosure of REC retirements and may be interested in direct contracting with developers of new projects.

2) Delivery and retirement process: If purchase volumes are significant, buyers may want direct delivery of RECs to their own registry accounts, or, at the very least, beneficial owner confirmation for each REC retired in their name. If the majority of buyers buy small volumes, retirements can generally be made in aggregate. Another question to consider is how often retirements will be done. Most times annually is sufficient, but some buyers may have different requirements, and small purchasers may only be signed up for periods of less than a year.

3) Disclosures: Utilities should consider how documentation of retirements will be disclosed to customers. Should it be direct notification via the registry, PDF certificates documenting the beneficial owners' serial numbers, and so on, or an annual report provided by the utility to all customers?

These questions are worth considering as programs are being developed. Registries support the many options utilities have, so it is ultimately a question for the utility on how to provide the most efficient process that meets the requirements of the primary customers that are expected to participate in the program. 


\subsubsection{Utility-Owned REC Registry}

A utility-owned and operated REC registry allows for the greatest amount of control of system and product design and pricing but requires the most upfront investment in time and money. Establishing a registry would entail extensive effort to meet the international standards expected by the market. It would include establishing protocols and procedures to ensure transparency of process and validity of the RECs produced to provide the market confidence in the product. REC system infrastructure requires IT infrastructure for secure collection and management of data, software to process information, and human resources to manage the program and plan and carry out program functions.

The benefits of a utility-owned REC registry are that the utility would have control of the system design and the potential long-term financial efficiency. System control could make dealing with country- or utility-specific issues easier. For example, it simplifies maintaining alignment with changes in pertinent national regulations. Self-ownership also presents opportunities to save financial resources on operations through scale and efficiency gains. If designed properly, costs could be covered by administrative fees that can be rolled into REC costs.

Carrying this out requires specific technical expertise and experience to help meet international best practice standards and navigate program design challenges. Design and implementation could be done through consulting services of technical experts to ensure the program meets international best practices. Once a utility develops expertise, it could perform all operations and management functions in-house.

\subsubsection{Hybrid Approach}

A hybrid approach falls between full reliance on an existing REC tracking system and developing one that is utility-owned and operated. This involves the utility working with a REC tracking system operator to tailor a commercial tracking system to meet needs identified by the utility. Existing REC tracking systems typically have established protocols, structures, and, in some cases, partners for project registration, generation verification and validation, and other operating components. But system operators may be willing to work with a utility to modify standing procedures as necessary to meet the needs of a given context, as long as changes meet international requirements.

For example, some utilities may wish to participate as both a REC generator and REC issuer. Under existing REC tracking systems, these functions are separated to disincentivize misreporting, but arrangements can be made to establish firewalls between generation and issuing bodies. As another example, a utility may wish to use an existing REC tracking system provider, but also hire it to support the design and implementation of a program that fully "plugs" existing tracking system mechanisms into an RE procurement product that can be made available to customers through a GPP. ${ }^{8}$ In a third example, utilities and tracking system operators have the option of including other stakeholders, such as government regulators, business associations, or civil society advocates into the management or operation of a tracking system to facilitate broad buy-in.

\footnotetext{
${ }^{8}$ The Sunnyside Up program in Singapore offers an example of this in effect: https://pacificlight.com.sg/promotions/sunnysideup.
} 


\section{Potential Costs and Revenues of a REC-Based Program}

Although a principle function of REC-based programs is to drive investment in RE capacity, the decision to implement a program to a significant extent depends on the affordability of doing so, which further depends on the balance between program costs and potential revenues. The sections below outline the costs that go into REC-based programs and what drives the revenues that can offset those costs. Importantly, in traditionally regulated markets, utilities are generally required to ensure participants in a program pay the full cost of that program, not passing costs on to other ratepayers.

\subsection{Cost Categories}

As noted in the previous sections, REC-based programs can be set up either by utilizing an existing REC tracking system or by establishing a new program. The approach selected will impact program initiation and operating costs, with costs for existing REC tracking systems being relatively well-known and costs for developing a new system largely dependent upon existing utility infrastructure and expertise.

The published fee structures for the I-REC Standard and TIGRs tracking systems have different fee structures, but they can generally be described as charging fees for: device registration, account type (such as trading and redemption accounts), and the various REC transactions (such as REC issuance and transfers). Their fees (as of March 2020) are shown in Table 9. 
Table 9. I-RECS and TIGRs Fee Schedules

\begin{tabular}{|c|c|c|c|}
\hline \multicolumn{2}{|l|}{ I-REC Standard* } & \multicolumn{2}{|l|}{ APX/TIGRs Registry** } \\
\hline \multicolumn{2}{|c|}{$\begin{array}{l}\text { Participant Fees (Trade and Redemption } \\
\text { Accounts) }\end{array}$} & \multicolumn{2}{|l|}{ Annual Subscription Fees } \\
\hline $\begin{array}{l}\text { One-time trade account } \\
\text { opening fee }\end{array}$ & $\$ 500$ & Project Account & $\$ 0$ \\
\hline Annual trade account fee & $\$ 2,200$ & General account & $\$ 1,000$ \\
\hline $\begin{array}{l}\text { Additional redemption account } \\
\text { fee }\end{array}$ & $\$ 0$ & Retail aggregator account & $\$ 1,000$ \\
\hline Redemption fee (per MWh) & $\$ 0.065$ & Retirement account & $\$ 250$ \\
\hline \multicolumn{2}{|l|}{ Registrant fees (Central issuer) } & QRE account & $\$ 0$ \\
\hline Registrant application & $\$ 0$ & Micro generator $(<250 \mathrm{~kW})$ & $\$ 100$ \\
\hline $\begin{array}{l}\text { One-time device registration (5- } \\
\text { year validity) }\end{array}$ & $\$ 1,100$ & Small generator (250kW-1MW) & $\$ 200$ \\
\hline $\begin{array}{l}\text { Device renewal after 5-year } \\
\text { validity }\end{array}$ & $\$ 40$ & Medium generator (1-10MW) & $\$ 500$ \\
\hline \multirow[t]{5}{*}{ Issuance fee (per MWh) } & $\$ 0.027$ & Large generator $(>10 \mathrm{MW})$ & $\$ 1,000$ \\
\hline & & \multicolumn{2}{|l|}{ Volumetric Fees: } \\
\hline & & Issuance fee (per certificate) & $\$ 0.03$ \\
\hline & & $\begin{array}{l}\text { Transfer fee (per certificate, paid } \\
\text { by recipient) }\end{array}$ & $\$ 0.01$ \\
\hline & & Retirement fee (per certificate) & $\$ 0.03$ \\
\hline
\end{tabular}

*Source: Irecstandard.org

**Source: Apx.com

In addition to the tracking system fees shown in Table 9, utilities will incur additional internal costs, such as administrative and operating costs, such as those for program establishment, dayto-day operations, and for resources to analyze REC program activities and results. For programs seeking to integrate RECs with GPPs, there will be additional planning and implementation costs, including those for program marketing to ensure uptake.

Costs for setting up and operating a new self-owned REC tracking system involve resources needed for establishing program policy, planning and design. To be effective, these require 
access to policy and REC planning expertise, which can be developed in-house or through external consulting services. Once the program is designed, there will be costs associated with IT infrastructure, program administrators and day-to-day operators, software development or acquisition, long-term maintenance, and system upgrades for system security and policy changes.

In total, these costs are typically a small portion of the overall REC price, which should be taken into account when developing a REC-based program.

\subsection{REC Pricing}

The value of a REC can be difficult to forecast and is a product of supply and demand. Higher quality RECs, such as those that have been certified in a tracking system from new-build solar or wind resources, are more likely to command a higher price. If government mandates are in place that require RECs to meet RE goals (such as an RPS), REC prices may be higher if demand exceeds supply. Figure 6 provides details of solar REC prices in PJM, a multistate market in the eastern United States. A significant factor affecting these prices is distinct policy environments including state-level RPSs. For example, Washington, D.C. has a high solar carve-out and difficulty siting new solar projects, keeping supply low and prices high. On the other hand, states like Ohio and North Carolina have a lower solar target and plenty of supply, leading to lower REC prices (PJM n.d.).

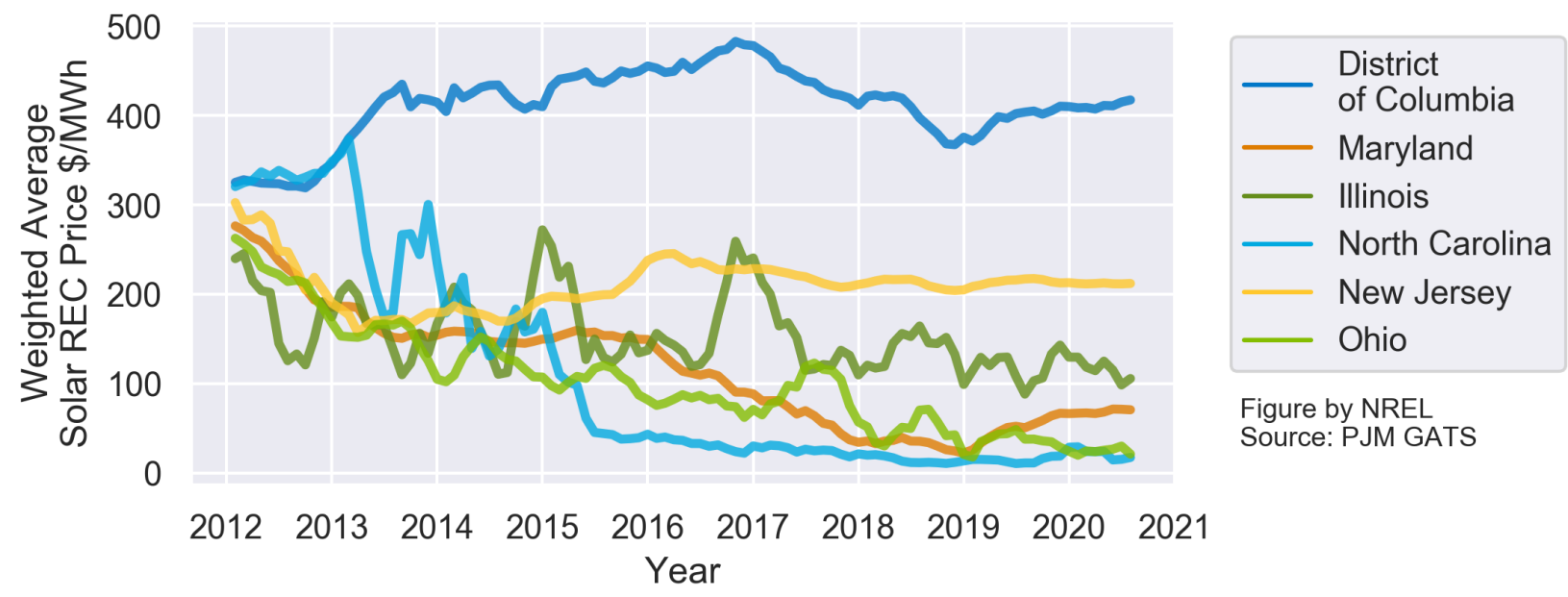

Figure 6. U.S. solar REC price variance by state 


\section{Summary and Conclusions}

Organizations across the world are working with governments and utilities in traditionally regulated markets to create new RE programs. Creating successful programs requires that utilities provide assurance that customers are getting what they are paying for; the internationally accepted way to do this is to create a program that uses RECs as an accounting mechanism. Using RECs, paired with a strong tracking system that verifies and documents ownership, generation, and transfers, ensures that RE is not double-sold, double-counted, or double-claimed. These tracking systems ensure reliability and give the market confidence to monetize the RECs.

Utilities or governments can enhance REC values by designing programs that use RECs from projects that support the corporate goals of procuring RE that is credible, affordable, and impactful. Utilities and governments can engage stakeholders to develop awareness of customer demand characteristics within their service territory or borders.

REC-based programs offered by utilities can include green pricing and green tariff programs, as well as selling RECs directly to brokers or marketers for sale to corporate customers. In some electricity markets, third-party PPAs or leases are allowed, which provide electricity customers the ability to contract directly with an RE generator or supplier instead of working through their utility company.

When setting up a REC-based program, utilities should consider whether using an established REC registry, creating a custom registry, or using a hybrid approach will work best for them, based on their program goals and internal staff capacity. However, developing a REC-based program is a larger effort than simply tracking RECs. Utilities may want to develop an implementation roadmap, which includes addressing the goals of the REC-based program, what types of RE it will include, and alignment with other government clean energy-related programs.

Finally, utilities may want to consider the expected costs and revenues of a REC-based program. A new program will incur administrative costs and marketing costs, in addition to REC tracking system costs. Program revenue will be highly dependent on the cost of the RE resource and additional supply issues such as the level of a FIT and/or strength of an RPS.

The range of options afforded by the flexibility of RECs has given rise to product innovation around the world. Key examples include:

- In Malaysia, the government is studying market liberalization to give corporations more flexibility in purchasing clean energy. The government has also established a REC tracking process using the TIGRs registry.

- In Japan, corporations are signing PPAs with generators that have received FIT payments. Because of this, the corporations also buy RECs from the Japan Electric Power Exchange to make valid claims that they are using RE.

- In Europe, electricity suppliers purchase GOs and offer them to customers via green pricing programs; customers can see where the GOs are sourced from, and the products are regulated by the European Union. The European Parliament also recently decided to allow corporations to purchase GOs directly from generators, without going through their electricity supplier. 
- In the United States, green tariffs are developing rapidly, due to efforts by large tech companies to ensure they can source RE that is cost-effective. Green tariffs allow customers to purchase RE from an individual facility, via their utility, typically on a long-term basis, with the potential for cost savings.

- In the Philippines, third-party PPAs allow large customers to sign contracts with RE generators, though the RECs go to the distribution utility, rather than the customer. 


\section{References}

Alarcon, Constant, and Marie Reynolds. 2019. RE100 Progress and Insights Annual Report. The Climate Group. http://media.virbcdn.com/files/5c/aa8193f038934840-

Dec2019RE100ProgressandInsightsAnnualReport.pdf.

APX. 2018. "TIGRs Registry Requirements for Qualified Reporting Entities." https://apx.com/wp-content/uploads/2017/07/QRE-Requirements.pdf.

Castro, Laura, James Ellis, and William Nelson. "2020 Mexico Power Market Outlook: End of an Era." Presented at the Bloomberg New Energy Finance (BNEF) Webinar, April 14, 2020.

CDP. 2020. CDP Technical Note: Accounting of Scope 2 Emissions.

https://b8f65cb373b1b7b15feb-

c70d8ead6ced550b4d987d7c03fcdd1d.ssl.cf3.rackcdn.com/cms/guidance docs/pdfs/000/000/41 5/original/CDP-Accounting-of-Scope-2-Emissions.pdf?1479752807.

Clean Energy Investment Accelerator. 2019. "Survey: Corporate Preferences for Renewable Energy Products.” Unpublished data, July 2019.

CRS. 2012. Renewable Energy Certificates, Carbon Offsets, and Carbon Claims: Best Practices and Frequently Asked Questions. (Clean Energy Investment Accelerator 2019).

Google. 2016. Achieving Our 100\% Renewable Energy Purchasing Goal and Going Beyond. https://static.googleusercontent.com/media/www.google.com/en//green/pdf/achieving-100renewable-energy-purchasing-goal.pdf.

Harrison, Kyle. 2020. "1H 2020 Corporate Energy Market Outlook.” BloombergNEF.

Heeter, Jenny, and Eric O'Shaughnessy. 2019. "Status and Trends in the Voluntary Market (2018 Data)." Presented at the Renewable Energy Markets Conference 2019, San Diego, CA, September 6. https://www.nrel.gov/docs/fy20osti/74862.pdf.

Heeter, Jenny, Ravi Vora, Shivani Mathur, Paola Madrigal, Sushanta Chatterjee, and Rakesh Shah. 2016. Wheeling and Banking Strategies for Optimal Renewable Energy Deployment: International Experiences. Golden, CO: NREL. NREL/TP-6A20-65660. https://www.nrel.gov/docs/fy16osti/65660.pdf.

Lowder, Travis, Jeffrey Logan, and Emily Chen. 2019. "Innovative Utility Offerings at the Distribution Edge: Case Studies from Around the Globe." Technical Report, 37.

Kizzier, Kelley, Kelly Levin, and Mandy Rambharos. "What You Need to Know About Article 6 of the Paris Agreement." Climate 411. December 2, 2019.

http://blogs.edf.org/climate411/2019/12/02/what-you-need-to-know-about-article-6-of-the-parisagreement/. 
Mortlock, Amanda. "Maximizing the Value of Your Green Power Programs." Utility Dive. November 20, 2019. https://www.utilitydive.com/spons/maximizing-the-value-of-your-greenpower-programs/567475/.

Motyka, Marlene, Stanley Porter, Suzanna Sanborn, Andrew Slaughter, and Scott Smith. 2019. "Deloitte Resources 2019 Study, Energy Management: Balancing Climate, Cost, and Choice."

O’Shaughnessy, Eric, Jenny Heeter, and Jenny Sauer. 2018. "Status and Trends in the U.S. Voluntary Green Power Market (2017 Data).”

PJM. "PJM Generation Attribute Tracking System, Solar Weighted Average (REC) Price." Accessed March 12, 2020. https://gats.pjmeis.com/gats2/PublicReports/SolarWeightedAveragePrice.

PwC. 2016. Corporate Renewable Energy Procurement Survey Insights: June 2016. https://www.pwc.com/us/en/sustainability-services/publications/assets/pwc-corporate-renewableenergy-procurement-survey-insights.pdf.

RECS International Secretariat. 2018. "Renewables Good Practice (ReGP) Guidance Document: Good Practice Guidelines for Reliable Energy-Attribute Procurement."

Sindicatum. 2019. “Sindicatum's Reneum Platform Issues First Batch of Tokens for Renewable Energy Certificates.” https://sindicatum.s3.ap-south-1.amazonaws.com/files/reneum-institutetoken-distribution.pdf.

Sotos, Mary. 2015. "GHG Protocol Scope 2 Guidance." https://ghgprotocol.org/sites/default/files/standards/Scope $\% 202 \% 20$ Guidance Final Sept26.pdf.

Takase, Kae, Masaya Ishida, and Shailesh Telang. 2020. Renewable Energy Market Briefing, Japan. http://media.virbcdn.com/files/28/dcf62df1869a1abd-

RE100JapanMarketBriefingJanuary2020-use.pdf.

Unilever. 2019. "We Now Use 100\% Renewable Electricity across Five Continents." September 16, 2019. https://www.unilever.com/news/news-and-features/Feature-article/2019/we-now-use100 -per-cent-renewable-electricity-across-five-continents.html.

EPA (U.S. Environmental Protection Agency). 2018. "Utility Green Tariffs.” Overviews and Factsheets. July 26, 2018. https:/www.epa.gov/greenpower/utility-green-tariffs. 


\section{Appendix A. Implementation Steps}

REC-based program design and implementation steps depend on the outcomes a utility or regulator desires from the program, limitations posed by market structure and customer demands, and the desired program features. Key decisions the utilities or regulators will have to make to determine the implementation strategy are:

1. What are the goals of the REC-based program?

2. Should an existing tracking system be used, or is an implementer-owned system preferred?

3. Will REC generation be stand-alone, or will RECs be integrated with a GPP?

Table A- 1 provides a list of questions for utilities to consider when deciding how to design a program, and to what extent they should be involved in REC program management. Table A- 2 highlights the key milestones on the path to implementing a program and selling REC-based RE products. These two tables can serve as the basis for REC-based procurement program implementation. 
Table A- 1. REC-Based Program Design Considerations

\begin{tabular}{|c|c|}
\hline Question & Context \\
\hline \multicolumn{2}{|l|}{ REC Scheme } \\
\hline $\begin{array}{l}\text { What are the utility's goals for } \\
\text { establishing a REC-based } \\
\text { program? Is it to drive private } \\
\text { sector investment? Is it to } \\
\text { grow customer demand? Is it } \\
\text { primarily for additional } \\
\text { review? }\end{array}$ & $\begin{array}{l}\text { REC-based programs should be designed to } \\
\text { encourage financial flows in a way that support utility } \\
\text { goals. REC best practices encourage programs to be } \\
\text { designed to drive RE installation through private } \\
\text { sector investment, not serve only as revenue for } \\
\text { utilities; programs that do not encourage new RE will } \\
\text { have limited appeal to many corporate buyers, so will } \\
\text { have lower prices. Utilities seeking to drive } \\
\text { investment should expect to share revenues, while } \\
\text { those seeking only revenue should design for low } \\
\text { margins and large volume. }\end{array}$ \\
\hline $\begin{array}{l}\text { Does the utility want to sell } \\
\text { RECs as stand-alone } \\
\text { transactions or integrated with } \\
\text { a GPP? }\end{array}$ & $\begin{array}{l}\text { Stand-alone RECs registration and sales may be } \\
\text { easier to implement but do not offer the utility many } \\
\text { options in product design. }\end{array}$ \\
\hline $\begin{array}{l}\text { Will the utility fully own and } \\
\text { operate the REC tracking } \\
\text { system or engage an existing } \\
\text { REC registry program? }\end{array}$ & $\begin{array}{l}\text { For utility's consideration: budget, time, contractor } \\
\text { procurement process. }\end{array}$ \\
\hline $\begin{array}{l}\text { Does the utility prefer to } \\
\text { develop and integrate the } \\
\text { tracking system on its own, } \\
\text { with contractor support, or } \\
\text { purchased off-the-shelf? }\end{array}$ & See immediately above. \\
\hline $\begin{array}{l}\text { How does the utility intend to } \\
\text { fund and operate its REC- } \\
\text { based program (near and } \\
\text { longer term)? }\end{array}$ & $\begin{array}{l}\text { The utility should identify its funding sources and } \\
\text { administrative requirements to cover near-term costs } \\
\text { associated with selected system design and } \\
\text { implementation, and long-term program operating } \\
\text { structures and resources. }\end{array}$ \\
\hline RE Attributes Data & \\
\hline
\end{tabular}




\begin{tabular}{|l|l|}
\hline $\begin{array}{l}\text { Which RE generators does } \\
\text { the utility intend to produce } \\
\text { RECs from? Indicate which } \\
\text { are: (1) Utility-owned; (2) } \\
\begin{array}{l}\text { Contracted through PPA; and } \\
\text { (3) Other (specify). }\end{array}\end{array}$ & $\begin{array}{l}\text { This information is needed to estimate program scale } \\
\text { and to identify generators to prioritize for potential } \\
\text { pilot implementation. Need to know generator type, } \\
\text { size, annual kWh production, age, ownership status } \\
\text { and time horizon, on/off grid, location. Priority RE } \\
\text { generator types are dictated by market demand } \\
\text { (typically newer than 5 years and not large hydro). }\end{array}$ \\
\hline $\begin{array}{l}\text { Are there any RE generators } \\
\text { already dedicated to specific } \\
\text { customers? }\end{array}$ & $\begin{array}{l}\text { This information is needed to qualify the list of } \\
\text { generators identified in \#6 above. }\end{array}$ \\
\hline $\begin{array}{l}\text { Policy and Coordination } \\
\text { Are there policy- or } \\
\text { regulation-related } \\
\text { considerations the utility must } \\
\text { address to satisfy regulators? }\end{array}$ & $\begin{array}{l}\text { The utility may need to coordinate with or receive } \\
\text { approvals from the energy, financial, market, and } \\
\text { other regulators for developing new programs, } \\
\text { engaging with foreign companies, initiating and } \\
\text { managing new revenue streams, and so on. }\end{array}$ \\
\hline $\begin{array}{l}\text { Has the utility coordinated } \\
\text { with the relevant } \\
\text { organizations regarding } \\
\text { existing or pending carbon } \\
\text { trading programs? }\end{array}$ & $\begin{array}{l}\text { Close coordination between RE and GHG programs } \\
\text { is required to eliminate risk of double-counting and } \\
\text { double-selling (which would depress REC prices). }\end{array}$ \\
\hline $\begin{array}{l}\text { 10. How is RE or GHG attribute } \\
\text { ownership handled in active } \\
\text { PPAs? Is there a strategy for } \\
\text { handling REC ownership for } \\
\text { IPPs? }\end{array}$ & $\begin{array}{l}\text { Uncoordinated REC ownership rule changes could } \\
\text { anse market confusion, legal challenges, and } \\
\text { damage investor confidence. }\end{array}$ \\
\hline $\begin{array}{l}\text { 11. Is the government } \\
\text { ans }\end{array}$ & $\begin{array}{l}\text { REC programs can be designed to accommodate } \\
\text { mandatory and voluntary RE programs, and early } \\
\text { planning can facilitate REC program design. }\end{array}$ \\
\hline
\end{tabular}


Table A- 2. REC Program Implementation Milestones

\begin{tabular}{|c|c|c|}
\hline Milestone & Action & Outcomes/Outputs \\
\hline \multirow{3}{*}{$\begin{array}{l}\text { 1. Determine REC } \\
\text { integration pathway } \\
\text { What are the goals? How } \\
\text { will the utility utilize } \\
\text { RECs? As stand-alone or } \\
\text { integrated with green } \\
\text { pricing or tariff products? }\end{array}$} & $\begin{array}{l}\text { Consultation with } \\
\text { government, REC policy, } \\
\text { and REC tracking system } \\
\text { stakeholders }\end{array}$ & $\begin{array}{l}\text { Best practice-informed } \\
\text { and utility-approved } \\
\text { integration approach }\end{array}$ \\
\hline & & \\
\hline & $\begin{array}{l}\text { Internal utility deliberation } \\
\text { and approval of integration } \\
\text { approach }\end{array}$ & $\begin{array}{l}\text { Document detailing } \\
\text { approach }\end{array}$ \\
\hline \multirow{2}{*}{$\begin{array}{l}\text { 2. Define scale of utility's } \\
\text { eligible RE } \\
\text { Which RE does the } \\
\text { market demand? }\end{array}$} & $\begin{array}{l}\text { Meet with corporate } \\
\text { stakeholders to define } \\
\text { desirable/eligible RE }\end{array}$ & $\begin{array}{l}\text { Definition of eligible RE to } \\
\text { be used for RE products }\end{array}$ \\
\hline & $\begin{array}{l}\text { Compare results with utility } \\
\text { inventory of } R E\end{array}$ & $\begin{array}{l}\text { Document scale of utility's } \\
\text { REC-eligible RE }\end{array}$ \\
\hline \multirow{2}{*}{$\begin{array}{l}\text { 3. Determine REC system } \\
\text { owner/operator } \\
\text { arrangement } \\
\text { Use existing systems or } \\
\text { establish utility's own? }\end{array}$} & $\begin{array}{l}\text { Consultations between } \\
\text { utility and REC } \\
\text { policy/tracking system } \\
\text { experts }\end{array}$ & $\begin{array}{l}\text { Actionable information } \\
\text { and strategy for } \\
\text { implementation }\end{array}$ \\
\hline & $\begin{array}{l}\text { Internal utility deliberation } \\
\text { on owner/operator approach }\end{array}$ & $\begin{array}{l}\text { Documentation of } \\
\text { decision }\end{array}$ \\
\hline \multirow{5}{*}{$\begin{array}{l}\text { 4. Design REC system } \\
\text { What is the process for } \\
\text { generating and tracking } \\
\text { RECs? How to integrate } \\
\text { with green pricing or } \\
\text { green tariff program? }\end{array}$} & $\begin{array}{l}\text { Engage REC tracking } \\
\text { system providers to } \\
\text { discuss/document design } \\
\text { options and utility's role }\end{array}$ & Documentation of options \\
\hline & Solicit provider offers & Formal provider offers \\
\hline & $\begin{array}{l}\text { Internal utility deliberation } \\
\text { and/or external consultation } \\
\text { on option selection }\end{array}$ & $\begin{array}{l}\text { Documentation of } \\
\text { decision }\end{array}$ \\
\hline & $\begin{array}{l}\text { Select system } \\
\text { provider/partner }\end{array}$ & Provider contract \\
\hline & Final system design & $\begin{array}{l}\text { Documentation of final } \\
\text { system design }\end{array}$ \\
\hline $\begin{array}{l}\text { 5. Develop and implement } \\
\text { related policies and } \\
\text { rules }\end{array}$ & $\begin{array}{l}\text { Meet with regulators to } \\
\text { identify policy/regulation } \\
\text { needs }\end{array}$ & $\begin{array}{l}\text { Documentation of legal } \\
\text { considerations }\end{array}$ \\
\hline
\end{tabular}




\begin{tabular}{|c|c|c|}
\hline \multirow[t]{2}{*}{$\begin{array}{l}\text { Address legal } \\
\text { considerations. }\end{array}$} & $\begin{array}{l}\text { Set new rules (e.g., REC } \\
\text { ownership related to PPA- } \\
\text { based RE generation) }\end{array}$ & $\begin{array}{l}\text { New policies/rules } \\
\text { established }\end{array}$ \\
\hline & $\begin{array}{l}\text { Design and establish green } \\
\text { pricing/tariff program (if } \\
\text { applicable) }\end{array}$ & $\begin{array}{l}\text { Green pricing/tariff } \\
\text { program established }\end{array}$ \\
\hline $\begin{array}{l}\text { 6. Implement tracking } \\
\text { system } \\
\text { For either existing or } \\
\text { utility-owned. }\end{array}$ & $\begin{array}{l}\text { May include: } \\
\text { Engage and contract } \\
\text { verifier } \\
\text { Identify and procure } \\
\text { hardware/software } \\
\text { Establish operating } \\
\text { procedures } \\
\text { Organize and train staff. }\end{array}$ & $\begin{array}{l}\text { Fully operational and } \\
\text { market-ready REC } \\
\text { generation process } \\
\text { Integration with GPP (if } \\
\text { applicable }\end{array}$ \\
\hline $\begin{array}{l}\text { 7. Generate and track } \\
\text { RECs }\end{array}$ & $\begin{array}{l}\text { Pay program fees (if } \\
\text { utilizing existing tracking } \\
\text { system) } \\
\text { Register projects } \\
\text { Register electricity } \\
\text { generation. }\end{array}$ & RECs issued \\
\hline \multirow[t]{2}{*}{$\begin{array}{l}\text { 8. Engage the market and } \\
\text { sell }\end{array}$} & $\begin{array}{l}\text { Direct sales: } \\
\text { Develop direct contracts } \\
\text { and/or engage marketers } \\
\text { and brokers }\end{array}$ & RECs sold \\
\hline & $\begin{array}{l}\text { Integration with GPP: } \\
\text { Engage corporate buyers } \\
\text { and other voluntary REC } \\
\text { users } \\
\text { Market and sell RE } \\
\text { product. }\end{array}$ & RE and RECs sold \\
\hline
\end{tabular}

